\title{
Kral I. Aleksander Suikastı ve Türkiye-Yugoslavya İlişsilerine Etkisi
}

\author{
The Assassination of King Alexander I and Its Effects on Turkey-Yugoslavia Relations
}

\begin{abstract}
Aydın BEDEN *
Öz: I. Dünya Savaşı sonunda "Sırp-Hırvat Sloven Krallı̆̆ı"nın kurulmasında etkin rol alıp, babasının ölümünden sonra tahta çıkarak ülkesini idare eden I. Aleksander, vatanı ve milleti için fedakârlıktan çekinmeyen önemli bir asker, aynı zamanda iyi bir devlet adamı idi. Balkanlar ile Avrupa'da barış ve güvenliğin korunması gerektiğini düşünerek, Balkan Antantı, Küçük İtilaf gibi önemli uluslararası teşkilatların üyesi, hatta kurucularından biri olmuştur. Özellikle Balkan Antantı'nın kuruluş sürecinde gösterdiği gayretler, Türkiye Cumhuriyeti Cumhurbaşkanı Gazi Mustafa Kemal Paşa'nın da büyük takdirini kazandığından, iki liderin ortak mesaisi kardeşlik boyutuna ulaşan dostluğun oluşmasını sağlamıştır. Ancak bu dostluğun oluşmasından çok kısa bir süre sonra Yugoslavya Kralı I. Aleksander, Marsilya’da 9 Ekim 1934 tarihinde suikasta uğrayarak hayatını kaybetmiştir. Kralın ölümü, Türkiye Cumhuriyeti Devleti ile onun kurucusu Gazi Mustafa Kemal nezdinde önce büyük bir şaşkınlık ardından da derin bir üzüntü yaratmıştır. Bu yüzdendir ki, dostunu kaybetmenin acısını yaşayan Türk devlet erkânı ile kamuoyu, duyduğu sevgi ve saygının ifadesi olarak ülkesindeki birçok ilki merhum kral adına gerçekleştirmiştir. Çalışmada, Yugoslavya Kralı I. Aleksander'ın hayatından kısaca bahsedildikten sonra Marsilya Suikastı'nın sebepleri ve siyasi gelişmeler üzerinde durulacaktır. Akabinde Marsilya Suikastı ile hayatını kaybeden Kral I. Aleksander'ın ölüm haberinin Türkiye'de uyandırdığı akisler, olay karşısında başta Cumhurbaşkanı Gazi Mustafa Kemal olmak üzere siyasi erkânın tutumu, TBMM'nin faaliyetleri ve Yugoslav halkının üzüntüsünü paylaşan Türk milletinin sergilediği tavır incelenmeye çalışılacaktır. Devletlerarasındaki ikili ilişkilerin toplumdaki yankıları ve toplum psikolojisine etkileri bu bağlamda ele alınacaktır.
\end{abstract}

Anahtar sözcükler: Yugoslavya, Kral I. Aleksander, Türkiye, Balkan Antantı, Marsilya Suikastı

Abstract: Alexander I, who had an active role in the foundation of the "Serbian-Croat Slovenian Kingdom" after the end of First World War, who ruled his country after succeeding his father. He was an important soldier who was not afraid of any kind of self-sacrifice for his homeland and the nation and was also a decent statesman. Thinking that peace and security must be preserved across the Balkans and Europe, he became member and sometimes even one of the founders of the important international organizations, such as the Balkan Entente, and the Little Entente. In particular, the efforts he showed during the process of establishment of the Balkan Entente, he gained great appreciation from the President of the Republic of Turkey Mustafa Kemal Pasha and the friendship between these two leaders reached the level of brotherhood as a result of their shared efforts. However, after a short period King Alexander I of Yugoslavia was assassinated on October 9, 1934 in Marseilles. The death of the king came as a shock followed by deep sorrow for the Republic of Turkey and its founder Gazi Mustafa Kemal. It is for this reason that Turkish state officials and the community, who were experiencing the pain of losing a friend, broke much new ground in their country for the sake of the deceased king as a sign of love and respect. In this study, after mentioning the life of King Alexander I, reasons for the Marseilles Assassination and the politic developments are discussed. Following this, reflections of King Alexander I's assassination on Turkey, attitude of political officers, President Gazi Mustafa Kemal being in the first place, activities of TBMM and the manner adopted by Turkish people, who sympathized with Yugoslavian people, are examined. In this regard, echoes of mutual relations between states on the community are discussed.

Keywords: Yugoslavia, King Alexander I, Turkey, Balkan Entente, Marseilles Assassination

\footnotetext{
* Dr. Öğr. Ü., Akdeniz Üniversitesi, Edebiyat Fakültesi, Tarih Bölümü, Antalya. aydinbeden@akdeniz.edu.tr
} 


\section{Giriş}

I. Dünya Savaşı'nın sona ermesine müteakip, 1 Aralık 1918'de, Sırbistan, Hırvatistan, Slovenya, Makedonya, Karadağ ve Bosna-Hersek topraklarını kapsayacak şekilde "Sirp-Hırvat-Sloven Krallı̆̆ı” kurulmuştur (Baerlein 1922, 119-120; Sudetic 1992, 28-29). Haziran 1921'de kabul edilen Aziz Vitus Günü Anayasası (Vidovdan Anayasası) ile Sırp-Hırvat-Sloven kralı ilan edilen I. Aleksander ise, ülke içerisinde çıkan siyasi-etnik gruplaşma ve çatışmalardan ötürü aynı anayasayı 6 Ocak 1929'da askıya almış ve kısa bir süre sonra devletin ismini "Yugoslavya Krallığı" olarak değiştirmiştir (Başbakanlık Cumhuriyet Arşivi (BCA), Fon kodu/Yer No (Tarih), 30.10.0.0 / 250.691.15 (19 Ekim 1929); “The New Kingdom of Jugoslavia”, 1930, 297; Graham 1938, 31, 47, 99, 149-150; Armaoğlu 2015, 166-167. Ayrıca bk. Seton-Watson 1946, 217-225). Artık Yugoslavya kralı olarak anılan I. Aleksander, birçok farklı unsurdan oluşup, ciddi çatışma ve krizlerin eksik olmadığı ülkesini suikasta uğradığı 1934 yılına kadar yönetmiştir. Ülke içindeki krizlerin uluslararası sorunlarla birleşmesi sonucunda ise 9 Ekim 1934'te Marsilya'da düzenlenen bir suikast eylemi sonucunda hayatını kaybetmiştir. İki dünya savaşı arası dönemde Avrupa'da, özellikle de Balkanlarda huzur ve asayişin sağlanması, siyasi çalkantıların durdurulması konularında büyük gayretleri bulunan I. Aleksander, Türkiye ile de yakın ilişkiler kurduğundan yakın dönem Türkiye tarihi açısından önemli bir şahsiyettir. Bu nedenle çalışmada, kral I. Aleksander'ın hayatı, Türkiye ile ilişkileri ve öldürüldüğ̈̈ Marsilya Suikastı ile bu suikastın Türk kamuoyundaki akisleri incelenmek istenmiştir.

Araştırma konumuz ile ilgili daha önce Türkiye'de yapılmış en önemli çalışma Gülşah Kurt Güveloğlu'na aittir (Güveloğlu 2015, 249-269). Adı geçen çalışma, araştırmamıza temel olup oldukça faydalı katkılar sağlamıştır. Ancak ilgili makale ile benzerlik taşıyan bilgilerin dışında I. Aleksander'ın hayatına, Türkiye ile özellikle de Gazi Mustafa Kemal Paşa ile ilk ilişkilerin kurulmasına ve ölümünün Türkiye'de yarattığı etkilere burada daha fazla derinlik katılarak ele alınıp değerlendirilmesine çalışılmıştır. Yine, Güveloğlu'nun makalesinde kullanılan belge ve kaynaklara ilaveten daha farklı arşiv belgeleri ile kaynakların tespit edilmiş olması, konunun daha ayrıntılı bir şekilde irdelenmesi için bizi cesaretlendirmiştir.

\section{Yugoslavya Kralı I. Aleksander}

I. Aleksander, prenses Zorka ile prens Peter Karageorgeviç'in üçüncü çocuğu olarak 17 Aralık 1888 tarihinde Çetinje'de dünyaya gelmiştir. Baba tarafi, II. Mahmut döneminde, Sirp bağımsızlığı için çalışan köylü bir aileye dayanıyordu. Belki de bu yüzden, 1817'de Miloş Obrenovitch tarafından öldürülen büyük-büyükbabasından kalan bir mirasla, onun gibi tam bir Sirp milliyetçisi idi. Zira damarlarında Sırp olmayan tek bir damla kanın dahi olmadığı belirtilmektedir. Anne tarafından ise Karadağ kralı Nicholas'ın torunuydu. Otokratik ve disiplinli yapısı, buradan gelen aile bağlarına dayandırılmaktadır (Us 1936, 56; Seton-Watson 1935, 21; Zaman, 11 Teşrinievvel 1934, 7).

Miloş Obrenovitch, 1839 yılında tahttan indirilince yerine Aleksander Karageorgeviç (büyükbabas1) getirilmişti ancak o da 1858'e kadar iktidarda kalabildi. Sonra Obrenovitch ailesinden sırasıyla tekrar Miloş, ardından oğlu Micheal, onun akabinde yine aynı aileden Milan ve oğlu Aleksander Sırp tahtına oturdu. Aleksander bu aileye mensup son Sirp kralı idi. Zira 1903 yılında gerçekleşen askeri darbe sonucunda Karageorgeviç hanedanı kurucusunun torunu aynı zamanda kral I. Aleksander'ın da babası olan Peter Karageorgeviç kral ilan edildi (Hâkimiyeti Milliye, 16 Birinci teşrin 1934, 4).

Bunun öncesinde, 1890 yılında, henüz on beş aylık iken annesi prenses Zorka'yı kaybeden I. Aleksander, babası ve kardeşleri ile birlikte Cenevre'ye taşınmış ve burada aldığı eğitimle iyi 
derecede Fransızca öğrenmiştir. Bir süre sonra, Slavlar üzerinde 19. yüzyıldan bu yana devam eden Rus etkisi Aleksander'ın da hayatına tesir etmeye başladı. Keza, Rusları Slavlar için büyük bir umut olarak gören Peter, oğlu Aleksander'1 Rusya'ya gönderdi. Böylece 10 yaşına kadar kaldığı Cenevre'den St. Petersburg'a giderek Ecole des Pages'de eğitim görmeye başladı. 1903 yılındaki ufak ayrılığın dışındaki babası tahta çıktığı için Belgrat'a gelmiştir, 1898-1908 yılları arasında burada bulundu (Graham 1938, 74-77; Zaman, 11 Teşrinievvel 1934, 7; Cumhuriyet, 11 Teşrinievvel 1934, 8). Aleksander'ın aileden kaynaklanan söz konusu nitelikleri eğitim için gittiği St. Petersburg'da daha da keskinleşmiş, burada geniş bir Slav bakış açısı ile Rus sempatisi kazanmıştır. Bu ise sarsılmaz bir şekilde Rusya'ya bağlllık ve şükranlık duymasına yol açtı. Ancak aynı dönemde karakteri anti-demokratik bir hale de bürünmeye başladı (Seton-Watson 1935, 21). Aleksander, Petersburg'un ardından bir müddet İtalya'da kalmış (Güveloğlu 2015, 251), fakat kısa bir süre sonra ülkesine dönerek hızla yükselişe geçmiştir. Öyle ki, 1909'da Sırbistan tahtının varisi olup 1912 Balkan Savaşı'nda Sırp ordusunda görev alarak Osmanlı Devleti'ne karşı savaştı ve ilk askeri şöhretini Kumanova Muharebesi'nde kazandı. Bir yıl sonra ise Bulgar ordularıyla savaştı. I. Dünya Savaşı'nın hemen arifesinde, 11 Haziran 1914'te, 69 yaşındaki Sırbistan kralı Peter, genç prens Aleksander'1 kral naibi olarak atayarak onun Sırbistan kralı olması için tüm şartları hazırladı. Diğer taraftan Sırp ordusunun başarıları Bosna-Hersek’teki öğrencileri yoğun bir şekilde etkilediğinden, iki hafta sonra 28 Haziran 1914'te I. Dünya Savaşı'nı tetikleyen Avusturya-Macaristan İmparatorluğu Arşidükü'ne yönelik suikast gerçekleştirildi (Graham 1938, 80-82; Cumhuriyet, 11 Teşrinievvel 1934, 8; Zaman, 11 Teşrinievvel 1934, 7). Dolayısıyla, Avusturya-Macaristan İmparatorluğu ile Sırbistan arasında başlayıp tüm dünyaya yayılacak olan savaşın ilk kıvılcımının ateşlendiği dönemde I. Aleksander, krallık unvanı hariç Sırbistan'ın tek hâkimi idi.

I. Aleksander, I. Dünya Savaşı'na katılarak savaşta üstlendiği görevlerle önce halkının takdirini kazandı. Akabinde İttifak devletleriyle görüşmelere katılarak asker kimliğinin yanı sıra devlet adamı ve diplomat olarak da tecrübe kazandı (Güveloğlu 2015, 251). Özellikle 5 Nisan 1916 'da müttefiki İngiltere'den gelen bir heyete, bağlı bulunduğu hanedanlığın nihai amacını resmen açıklayarak; "zaferi nihaî tahakkuk ettiği takdirde "tek bir devlet halinde birleşmiş Yugoslav milletinin de, zaferin in'amindan müstefit olacağl”"nı ifade etmesi, geçmişten gelen tarihi emeli kendisinin gerçekleştirme arzusunda olduğunu göstermişti (Cumhuriyet, 11 Teşrinievvel 1934, 8).

Zaten savaşın ardından 1918'de Sırp-Hırvat-Sloven Krallığı'nın kurulmasıyla amacına ulaşan I. Aleksander, 1918-1921 yılları arası hükümet naibi olarak görev yapmış, 1903 yılından bu yana Sırp kralı olan babası Peter'in ölümü üzerine de 1921'de tahta çıkmıştır. Ardından 1922'de, Romanya kralı II. Ferdinand'ın ikinci kızı prenses Marie ile evlenmiş ve üç oğlu olmuştur. Prenses Marie ile evlenmesi, Marie'nin bir taraftan Rus Çarı II. Aleksander'nn soyundan geldiği için Slav kanı taşıması, diğer taraftan da kraliçe Victoria'nın soyuna dayandığı için İngiliz olması nedeniyle bilinçli bir seçimdi (Akşam, 10 Teşrinievvel 1934, 4; Zaman, 11 Teşrinievvel 1934, 7; Cumhuriyet, 11 Teşrinievvel 1934, 8; Graham 1938, 99). Böylece ülkesinin Rusya ile bağlantısı koparılmadığı gibi kaderi de Batı dünyası ile birleşmiş olacaktı.

Balkanlarda istikrarın sağlanması ve gerek Avrupa'da gerekse tüm dünyada hızla artan savaş emarelerinin ortadan kaldırılması adına yaklaşık 13 yıl boyunca devlet adamı ve diplomat niteliğini yoğun bir mesai ile ortaya koyan Yugoslavya kralı I. Aleksander, 9 Ekim 1934 günü Fransa'nın Marsilya kentinde bir suikasta uğrayarak hayatını kaybetti. 


\section{Suikastın Sebepleri}

Kral I. Aleksander'ın öldürülmesinin arkasında yatan sebepler gerçekte Avrupa devletlerinin birbirleriyle olan rekabetlerine dayanıyordu. Nitekim I. Dünya Savaşı'nın ardından Adriyatik kıyılarına sahip olacak şekilde Balkanlarda geniş bir Sırp-Hırvat-Sloven Krallı̆̆g'nın kurulması ne İtalya'yı ne de Avusturya ve Macaristan'ı memnun etmişti. Her üç devlet de sınırlarında büyük bir devletin kurulmasından rahatsız olduğu gibi bu devletin bazı kısımlarında da hak iddia ediyorlardı. Söz konusu krallığın parçalanması ve kendi toprak taleplerinin karşılanması ön planda tuttukları temel bir amaçtı. Bunlardan Avusturya, kendi iç meselelerinden ötürü konuyla fazla ilgilenmemiş fakat ülkedeki bazı kişi ve gruplar gizlice İtalya ve Macaristan ile işbirliğine gittiğinden dolaylı olarak gelişmelere müdahil olmuştur. Macaristan, krallık topraklarından Voivodina'yı geri almak istiyordu. İtalya ise Hırvatların ayrılarak bağımsız bir devlet kurmasını arzulamaktaydı ki böylece Hırvatistan'ı kontrol altına alarak Dalmaçya kıyıları üzerindeki emellerini gerçekleştirebilirdi (Graham 1938, 128-129).

I. Dünya Savaşı'nın ardından kurulan yeni statünün Avrupalı Devletlerarasında bu şekilde bir kamplaşmaya sebep olmasının dışında yine aynı kaynaktan beslenen farklı nedenler de bulunmaktadır. Avrupa tarafindan boykot edilen mallarına yeni pazarlar bulmak isteyen Almanya'nın Yugoslavya ile tam bu dönemde ticaret antlaşması yapması ve buna diğer Avrupa ülkelerinin tepki göstermesi, İtalya'nın Avusturya üzerindeki etkisi nedeniyle Almanya'nın İtalya ve Avusturya'ya baskılar yapması, hatta Temmuz 1934'te Avusturya Başbakanı Dollfuss'un bir grup Nazi tarafından öldürülmesi bu rekabet ve devletlerarası ilişkilerdeki olumsuz tutumların başlıca göstergeleridir (Ayrıntılı bilgi için bk. Güveloğlu 2015, 252-253).

Küçük Antant ülkeleriyle ilişkilerini geliştirmek isteyen Fransa ise mevcut gelişmelere kayıtsız değildi. Fransa Dışişleri Bakanı Barthou, Avrupa'daki Alman etkisine karşı başta Yugoslavya olmak üzere Küçük Antant ülkelerini ziyaret ederek, çeşitli niteliklerde antlaşmalar yapıp Balkan devletleri ile arasını sıcak tutmaya çalışıyordu (Güveloğlu 2015, 253). Aynı şekilde Yugoslavya kralı I. Aleksander da Fransa ile olan ittifakın sürmesini istediği gibi Küçük Antant'ın da sağlam bir destekçisiydi (Armstong 1935, 216).

Yugoslavya'yı etkileyen bir diğer faktör ise İtalya-Fransa rekabeti idi. İtalya, Fransa'nın özellikle Küçük Antant dolayısıyla Avrupa'da oluşturduğu nüfuzlu durumu hazmedememekteydi. Ayrıca İtalya'nın Doğu Adriyatik, yani Dalmaçya kıyıları üzerinde çeşitli emelleri vardı ve İtalyan kamuoyunun bir bölümü Adriyatik'in diğer tarafinda güçlü bir Yugoslav devletinin kurulmasını kabul edemiyor, dahası, bu devletin Fransız etkisi altında bulunması ciddi rahatsızlık yaratıyordu (Balkanicus 1934, 221-222). Arnavutluk ve Dalmaçya'ya göz koyan, bu yüzden de Balkan politikasını böl-yönet ilkesine göre şekillendiren Mussolini, Yugoslavya'daki ayrılıkçıları teşvik edip bilhassa Hırvat ayrılıkçılığı ile Macar revizyonizmine destek vererek Yugoslav birliğini dağıtmak istiyordu. İtalya'nın bu tehditlerine karşı Hırvat ve Slovenlerin yanında olmaya çalışan kral I. Aleksander ise dış politikada daha çok müttefiki Fransa ile birlikte hareket etmeye çalışmaktaydı (Seton-Watson 1935, 26-27; Güveloğlu 2015, 253-254).

Aslında belirtilen dış sebeplere içeride yaşanan gelişmelerin de katkı sağladığı söylenebilir. Çünkü Yugoslavya'daki iç karışıklıklar, İtalya gibi istikrarsız-parçalanmış bir Yugoslavya isteyen devletler için önemli firsatlar sunuyordu. Şüphesiz bunlar içerisinde en önemlisi Yugoslav halkı içerisinde olan ve 1921 Anayasası'ndan bu yana mevcut durumlarından sürekli rahatsız olup ayrılıkçı hareketlere kalkışan Hırvatlar ile Makedonlar idi. Özellikle Hırvatların kurmuş olduğu en başlıca örgüt "Ustasha" idi.

Ustasha (İsyancılar) örgütü; 7 Ocak 1929’da, yani anayasanın askıya alınmasından bir gün 
sonra Zagreb'de kuruldu. Resmi adı, “Hırvat Devrimci Örgütü” idi (Graham 1938, 127). Örgüt, kral Aleksander'ın parlamentoyu feshedip bütün siyasi parti, dernek ve örgütlerin faaliyetlerini yasaklayarak Yugoslavya'da otoriter bir yönetim kurması üzerine Ante Paveliç tarafından Gustav Perchetz ile birlikte kurulmuştu. Amacı, bağımsız bir Hırvat devleti kurmaktı. Aynı yıl Sofya'ya kaçan Paveliç ve Perchetz, burada Ivan Mihailov liderliğindeki Makedonya'nın Yugoslavya'dan ayrılmasını isteyen IMRO ile ittifak yaptı. IMRO, üs olarak seçtiği Bulgaristan'da kamplar kurarak eğitimlerini burada sürdürmekte ve sık sık sınırı geçerek Yugoslavya'ya karş1 eylemlerde bulunmaktaydı. Birleşmenin ardından bu örgütler, çeşitli gösteri ve terör olayları başlattılar. Halk gösterilerinde ağırlıklı olarak Sırplar ve Yugoslavlık aleyhinde konuşmalar yapılırken, verilen nutuklarda Hirvatlar ile Makedonların tutsak oldukları, yurtlarını kurtarmak için savaşmaları gerektiği yönünde telkinlerde bulunuluyordu (Seton-Watson 1935, Hâkimiyeti Milliye 21 Birinci teşrin 1934, 4; 29, 32-33; Banac 1997, 100-101; Morawski 2016, 71; Güveloğlu 2015, 256-257). Gerçekten de bu dönemde Sırplara karşı büyük bir güvensizlik besleyen Hırvatlar, kin ve düşmanlık içerisinde Sırp hâkimiyetinden kurtulmaya çalışıyorlardı. Bu amaç uğruna birçoğu Hırvatistan Köylü Partisi'ne katılırken, diğerleri de aynı çizgide farklı siyasi oluşumlar sergilediler. Bu grupların bir kısmı İtalya, Almanya ve Macaristan'a giderek Hırvatistan'ın bağımsızlığının tek yolunun Sırp yönetimine karşı şiddetle mücadele olduğuna karar verdi. Gittikleri ülkelerde ayrılıkçı Makedonlarla birlikte eğitim alıp, birçok bombalama, ayaklanma ve komplo eylemi gerçekleştirdiler (Tomasic 1940, 588-589). Zaten yapılan araştırmalarda, Ustasha örgütünün faaliyetleri sırasında İtalya Faşist Hükümeti’nden maddi yardım aldığı, Macaristan'dan destek gördüğü ve yine İtalya ve Macaristan'ın çeşitli bölgelerinde eğitim ve talim kamplarının bulunduğu anlaşılmıştır (Armstong 1935, 221-222; Güveloğlu 2015, 257). Hırvatlar gibi 1929 y1lı idari düzenlemelerinden, hatta daha önceye dayanan uygulamalardan olumsuz etkilenip bundan rahatsız olan bir diğer grup Makedonlar olduğu için onların da bağımsızlık için örgütlenip Ustasha ile işbirliğine gittikleri görülmektedir.

Sonuç olarak kral I. Aleksander, belki de Sırp-Hırvat-Sloven zamanında yavaş yavaş ortaya çıkmaya başlayan iç meseleleri çözebilmek ve tehlikeye giren ülke bütünlügünü koruyabilmek adına tüm iktidarı kendi elinde toplamaya karar vermiştir. Ancak 1929-1934 yılları arasında bu tür problemlerin hiçbirine çözüm getirememiş, aksine ülke tam bir polis rejimine dönüşmüştür. Özellikle Hırvatların uzlaştırılması için hiçbir ciddi adımın atılmaması, polisin de karıştığı bazı siyasi cinayetlerin işlenmesi, uygulanan baskı ve fikir özgürlüğüne getirilen kısıtlamalar ayrilıkçı kesimleri daha da hareketlendirdi (Seton-Watson 1935, 24-25; Banac 1997, 100-101). Gazeteci Ahmet Emin Yalman'ın deyimiyle kral Aleksander, diktatörlüğü Yugoslavlık fikrini yerleştirmek için kullanmıştır, fakat yıkıcı yöntemlerle hareket ettiğinden halklar arasındaki uçurum büsbütün artmıştır (BCA, 30.10.0.0/253.702.8 (25 Ekim 1936)).

Belgrat Elçiliği'nin 1933 yılına ait raporlarından da ülkenin içinde bulunduğu durumun endişe verici olduğu anlaşılmaktadır. Buna göre, açıklanan hükümet programında; halkta hoşnutsuzluğa sebep olan sıkıntıların derhal giderileceği ve gerekli düzenlemelerin yapılacağı, bu bağlamda; gerçek bir parlamenter sisteme geçiş için gerekli olan yeni bir seçim kanununun hazırlanacağı, belediye ve nahiyelere muhtariyet esasına dayanan demokratik bir şekil verileceği, yeni partilerin açılmasını sağlayacak düzenlemelerin yapılacağı belirtilmekte ve benzeri tüm iyileştirmeler için birçok yeni kanun hazırlığında olunduğu bildirilmişti. Ancak Yugoslav halkı, birçok şarta bağlanan bu kanun projelerinin gerçek parlamenter hayata geçişe hiçbir katkı sağlamayacağını düşünüyordu. Hatta bu gibi yalancı vaatlerden bıktıkları için krala, hükümete ve rejime karşı var olan kin ve nefretleri her geçen artmaktaydı. Hükümet ise aldığı sıkı tedbirlerle gösterilerin önüne geçmeye çalışıyordu. Bu tür baskılardan olmak üzere başta Hırvat ve Sloven liderler olmak üzere rejim aleyhtarı kimseler takip edilerek tutuklanmış, ülkede ve mecliste federa- 
lizm isteğinde bulunanlar gerek cebren, gerekse harici tehditlerin büyüklüğü ortaya konularak susturulmuştu (BCA, 30.10.0.0 / 251.695.32 (24 Nisan 1933); BCA, 30.10.0.0 / 251.696.2 (8 Mayıs 1933); BCA, 30.10.0.0 / 252.698 .19 (1934)). Dolayısıyla Yugoslavya'daki tüm bu iç karışıklıklar, hatta örgütlenmeye varacak boyuta ulaşan ayrılıkçı hareketler suikastın dâhili sebepleri olarak değerlendirilebileceği gibi dış mihrakların kendi amaçları uğruna kullanabilecekleri argümanlar da olacaktır.

Anlaşıldığı üzere Yugoslavya, içerde ayrılıkçı örgütlere karşı ülke birliğini korumak amacıyla kendi yöntemleri ile mücadele ederken, dış ilişkilerde Fransa'nın politikasına paralel, iki devletin ortak hareket etmesi ilkesine dayanan bir siyaset izlemekteydi. Bu durum, İtalya ve Avusturya tarafından hoş karşılanmazken, Yugoslavya'nın Almanya ile sürdürdüğü işbirliğinin de sona ermesi anlamına geliyordu. Bu ise Almanya'nın istediği bir sonuç değildi (Güveloğlu 2015, 253). Yine Macaristan Ustasha örgütünün önemli bir destekçisi olurken, Bulgaristan da Ustasha'nın müttefiki IMRO'nun karargâhı durumundaydı. Kısacası Yugoslavya dört taraftan kuşatılmıştı.

Böylesi bir ortamda Küçük Antantı destekleyen Fransa, Dışişleri Bakanı Barthou'yu çeşitli temaslarda bulunması için Avrupa'nın çeşitli başkentlerine göndermiş ve Bakan Prag, Bükreş, Varşova ve Belgrat'a ziyaretlerde bulunmuştur. Fransız Dışişleri Bakanı'nın ziyaretine karşılık Yugoslavya kralı I. Aleksander'ın da iade-i ziyaret için Eylül 1934'de Sofya'yı, Ekim'de de Fransa'yı ziyaret edeceği duyurulmuştur. Zaten suikast hazırlıkları da bu süreçte başlamıştır (Güveloğlu 2015, 254).

\section{Siyasi Gelişmeler ve Tansiyonun Yükselmesi}

I. Aleksander'ın tek amacı, Balkanlarda istikrarı sağlayıp barışı güvence altına almaktı. Batı Avrupa'daki barıştan çok Balkanlardaki barışla ilgileniyordu. Bunun için de Balkan Yarımadası'ndaki ulusların dayanışma içinde olması gerekiyordu. I. Aleksander, kurulacak bir Balkan Paktı ile bunun tesis edilebileceğini düşündüğü için Ağustos-Eylül 1933’teki Avrupa gezisinden dönen Bulgaristan kralı Boris ile Belgrat İstasyonu'nda görüştü, onu ikna etmeye çalıştı. Ancak Boris, ülkesindeki Makedon IMRO örgütünün faaliyetlerinden çekinmekte ve Yugoslavya ile bir antlaşma yapılması halinde öldürülebileceğinden korkmaktaydı. Bulgaristan kralının daveti üzerine şansını bir kez daha denemek isteyen I. Aleksander, 18 Eylül 1933'de Bulgaristan'a giderek Varna'da Boris'i tekrar ikna etmeye çalışmış ancak başaramamıştır (Graham 1938, 180-186).

Kararlı olan I. Aleksander, deniz yoluyla ülkesine dönerken diğer Balkan ülkelerini de ziyaret etti. Balkan Paktı'nın artık kurulması gerektiğine dair Türkiye ile hem fikir olduğunu gördüğü 4 Ekim 1933'teki Türkiye ziyareti bu açıdan oldukça önemlidir. Üstelik bu görüşmede Mustafa Kemal Paşa, Balkan Paktı'nın Küçük Antant ile birleştirilmesini ve Sovyet Rusya'nın desteğinin alınmasını öne sürmüştür (Graham 1938, 189).

Ardından Korfu Adası (Yunanistan) ile Arnavutluk'a gitti. Korfu'da Yunan yetkililere, Balkan devletlerinin tek başlarına İtalya ile mücadele edemeyeceklerini, lakin kurulacak bir paktın İtalya'ya karşı sigorta anlamına geleceğini anlattı. Pakt, İtalya ile çatışma anlamına gelmediği için Yunanlıların korkmalarını gerektirecek bir durum yoktu. Arnavutluk'ta ise durum başka idi. Burada Arnavutluk üzerinde hiçbir toprak taleplerinin olmadığını garanti ederek onu bağımsız bir devlet olarak görmek arzusunda olduğunu iletti. Açıklamanın nedeni, İtalya'nın Arnavutluk'u nüfuzu altına alarak burada kurduğu himaye ile Balkanlarda bir üs elde etmesiydi. Dolayısıyla IMRO örgütüne verdiği destekle bir yandan Makedon coğrafyası ile Bulgaristan'dan diğer yandan da Arnavutluk'tan yapılacak eşzamanlı bir İtalyan saldırısı, Yugoslavya'yı zor durumda bırakabilirdi. Kısacası Küçük Antant, anti-revizyonist devletler safinda yer alan Yu- 
goslavya için Avusturya ve Macaristan revizyonizmine karşı bir güvenceyse, Balkan Antantı da İtalya'ya karşı bir güvence olabilirdi (Graham 1938, 190, 192).

Ülkesine dönen Yugoslavya kralı, özellikle Bulgaristan konusunda ümidini yitirmemek için kral Boris ile bir kez daha görüştü, ancak sonuç yine olumsuzdu. Görüşmeden sonra edindiği izlenimleri Aralık 1933'te Ankara'ya aktaran I. Aleksander; Bulgar kralı Boris'in Yugoslav Hükümeti'nin sınırda kendilerine zorluk çıkardığından serzenişte bulunması üzerine kendisine, sınırdaki tedbirlerin güvenlik maksadıyla olup özellikle Bulgaristan'daki Makedon komitacılarının sürekli saldırılarına maruz kaldıkları için böyle bir yönteme başvurduklarını, fakat komitacıların tecavüzlere son vermesi halinde derhal tedbirlerin kaldırılabileceğini söylemiştir. Bunun üzerine kral Boris, Bulgaristan’a iltica edip ülkelerine dönemeyen Makedonyalılar için Yugoslavya'da genel bir af çıkarılmasını önermiştir. Teklifi kabul eden ancak geleceklerin herhangi bir asayişsizlik yaratmamaları için Bulgar Hükümeti'nden garanti isteyen Aleksander, ayrıca adi suçlardan yargılananlar ile komitacıları asla af kapsamına alamayacağını belirtmiştir. Karardan memnun olan Boris, böylelikle insan gücü kalmayacak olan komita örgütlerinin faaliyetlerinin azalacağını düşünüyordu. Bulgar kralı gerçekten Makedon Komitacılarının faaliyetlerinden tedirginlik duymaktaydı. Bizzat Aleksander'a; "Makedonya komitasından çekindiğini ve bu bapta yapılacak her icraatta kendisinin kellesi mevzubahis olabileceğini" söylemişti. Bunu pek inandırıcı bulmayan Yugoslav kralının manidar bir şekilde Boris'e bakması üzerine ise; "görüyorum ki sizde de benim Makedonya komitasının başında bulunduğum hakkında bir kanaat var" denilmesine sebep olmuş ve Aleksander cevaben; "evet, şimdiye kadar Makedonya komitasının yapmış olduğu icraata hükümetin seyirci nazarı ile bakması hasebi ile böyle bir fikirde bulunmakta hakl olduğumuzu siz de teslim edersiniz; fakat bundan sonra Makedonya komitasinın icraatına elbirliği ile mani olacak tedabir ittihaz olunur ise biz de bu fikirden vaz geçeriz" demiştir. Öte yandan kral I. Aleksander, sözü fazla uzatmayarak doğrudan Balkan Paktı'na getirmiştir. Varna görüşmesinden sonra yaptığı Türkiye ve Yunanistan ziyaretlerinden bahsedip Romanya da dâhil olmak üzere bu üç devletin liderleriyle yaptığı görüşmelerde ortak bir paktın kurulması yönünde karar alındığını, Bulgaristan'ın da bu ittifak içerisinde görülmek istendiğini ifade etmiştir. Lakin Boris, kayıtsız şartsız Bulgaristan'ın böyle bir pakta dâhil olmasının şahsı ile ülkesini küçük düşüreceğini söyleyerek teklifi geri çevirmiştir. Aleksander ise pakta dâhil olacak dört devletin hiçbir şekilde Bulgaristan'1 aşağılamak gibi bir amacının olmadığını, tam tersi onun refah ve emniyetinin sağlanmış olacağını belirterek ikna etmeye çalışmıştır. Hatta Aleksander, Bulgaristan'ın paktın dışında kalması halinde Balkanların o bölgesinin tüm dünya için bir fesat yuvası olarak değerlendirileceğini açıklayarak, ona son olarak, ortak yapılacak antlaşma formülünün kendileri tarafından hazırlanmasını teklif etmiştir. Boris son teklifi tereddütlü bir şekilde kabul ettiği için I. Aleksander, bir süre Bulgaristan'ın kararının beklenmesini, herhangi bir kabul veya formül gelmediği takdirde Bulgaristan'ın dişarıda bırakılarak dört devlet arasında paktın yapılması gerektiğini söylemiştir (Atatürk'ün Milli Dış Politikası 1994, 233-240; Şimşir 1996, 412-416).

Görüldüğü üzere Yugoslav kralı I. Aleksander, Bulgaristan'ın pakta dâhil olabilmesi için önce Bulgar kralının endişelerinin giderilmesi ve sınır ile komitacılık faaliyetleri başta olmak üzere tüm meselelerin çözülerek Yugoslavya-Bulgaristan ilişkilerinin düzelmesi gerektiğini düşünmüş, bu yoldaki teklifleri de kabul etmiştir. Ancak tüm çabalara rağmen Bulgaristan'ın pakta dâhil olmaması, onun gerçekten endişelerinin giderilmediği şeklinde yorumlanabileceği gibi belki de çeşitli endişelerden ötürü zaten girmek istemeyen Bulgaristan'ın Yugoslavya'dan taviz koparmak amacıyla bu tarz isteklerde bulunduğunu düşündürmektedir. Zira taleplerin hayata geçirilmesi ile Bulgaristan gerçekten de siyasi ve sosyal huzursuzluk kaynağı olan ülkesindeki komitacılardan kurtulmuş olacaktı. 
Öte yandan Bulgaristan'ın bu uzlaşmaz tavrında İtalya'nın etkisinin olduğu da unutulmamalıdır. İtalya Yunanistan'1, Türk-Yunan itilafının yapılıp, Balkan Antantı'nın kurulması kararı sonucunda anti-revizyonist bloka kaptırmıştı. Bulgaristan'1 da benzer şekilde kaybetmek istemediği için Bulgar-Yugoslav yakınlaşmasını engellenmeye çalışıyordu. Hatta herhangi bir ittifaktan önce kendisi ile birlikte Bulgaristan ve Arnavutluk tarafından oluşturulacak bir Balkan Paktı'nın Balkan Antantı'na alternatif olacak biçimde kurulmasına çabalamaktaydı (BCA, 30.10.0.0/226.525.20-17 (Ocak 1934)).

Tüm bu girişimler, kral I. Aleksander'ın kendisi ve ülkesi için asıl tehdidin nerelerden kaynaklandığını bildiğini gösterdiği gibi Balkan Antantı'nın kurulmasının da Yugoslavya için bir beka sorunu olduğunu ortaya koymaktayd. Yugoslavya, kendisi için bu kadar önemli bir güvenlik paktını böylelikle inşa etmeye çalışırken onun bu gayreti İtalya, Macaristan ve Avusturya gibi devletleri hiç memnun etmiyordu. O yüzden hedeflerine giden yoldaki en önemli engel olarak görülen I. Aleksander'ın ortadan kaldırılması, Yugoslavya'da büyük bir kaosa yol açacağı, ayrılıkçı halkların da toplumsal bir isyana başvuracağı öngörüsünde bulunulduğundan politikaları için elverişli bir ortam yaratabilirdi.

Zaten kral I. Aleksander'a yönelik ilk önemli suikast girişimi de tam bu dönemde, 17 Aralık 1933 'te gerçekleştirildi. Suikast, kralın 45. yaş günü kutlaması için gideceği Zagreb'de arabasının altına bomba atılması suretiyle gerçekleştirilecekti. Neyse ki, Ante Paveliç tarafından İtalya'dan gönderilen üç suikastçı yakalandığı için suikast başarısızlığa uğradı. Üstelik yakalananlardan Peter Oreb -diğer iki kişi Begovitch ve Pegorelats'dır- ismindeki Ustasha mensubu önemli itiraflarda bulundu (Graham 1938, 2-3, 26-27, 194-203). Olay üzerine İtalya'y1 protesto etmek isteyen kral Aleksander ise Fransa'nın baskıları üzerine kararından vazgeçti. Mart 1934'te mahkemeye çıkartılan üç suikastçı; İtalya'da 50-60 kişilik Ustasha kamplarında kalıp silah ve bomba eğitimi aldıklarını, Ante Paveliç, Gustav Perchetz, Milo Budak, Perçeviç gibi önemli Ustasha liderleri tarafından sık sık ziyaret edildiklerini belirtmişlerdir (Güveloğlu 2015, 254).

İtalya'ya herhangi bir tepki gösteremeyen Yugoslav Hükümeti, bir daha benzer girişimlerin yaşanmaması için faillerin üzerinden çıkan Macar pasaportu ve sınırlarına yakın yerlerdeki ayrıl1kçı örgüt kamplarından ötürü 13 Mart 1934'te Macar Hükümeti'ni protesto etti (Armstong 1935, 221). Gerçekten de gelişmeler, kral I. Aleksander'ın hayatına yönelik ciddi bir tehdidin var olduğunu, bir sonrakinde böyle başarısız bir teşebbüsle yetinilmeyeceğini gösteriyordu. Kısa bir süre sonra Marsilya Suikastı'nın cereyan etmesi ve faillerin verdiği ifadeler ise özellikle Macar Hükümeti'nin yapılan uyarıları ciddiye almadığını ortaya koyacaktır.

Diğer taraftan Zagreb'deki başarısızlık, İtalya'nın sabrını son noktaya getirdi. Ülkesinde faaliyet göstermesine izin verdiği Paveliç, yani Ustasha örgütü başarısızlığa uğramıştı ve onları her an sınır dışı edilebilirdi. Bu yüzden Paveliç, İtalya' daki konumunu korumak istiyorsa derhal başka bir girişimde bulunmalı ve bu sefer kesinlikle başarılı olmalıydı (Graham 1938, 27).

Bu esnada, 9 Şubat 1934'te, Türkiye, Yugoslavya, Yunanistan ve Romanya arasında Balkan Antantı imzalandı (6 Mart 1934 tarihinde TBMM'de onaylanan Balkan Pakt1, taraf devletlerin temsilcileri tarafından Atina'da imzalanmıştır. Bk. Düstur 1955, 118-119). Bulgaristan'da ise aynı yıl önemli gelişmeler yaşanmaya başlandı. Hükümet değişikliği ile iktidara gelen yeni yönetim, özellikle ülkedeki IMRO örgütünün faaliyetlerini sona erdirecek bazı kararlar alıp örgüt yuvalarını basmış, silah ve mühimmatlarına el koyup bazı elebaşlarını tutuklamıştır. Gelişme, Yugoslavya tarafından memnuniyetle karşılandı. Ancak önemli bir IMRO lideri olup kral I. Aleksander'ın katili de olacak olan Vlada'nın emir aldığı kişilerden Ivan Michailof Türkiye'ye kaçmıştı. Her ne kadar Ivan Michailof, Mustafa Kemal Paşa'nın verdiği emirle yakalan- 
mış olsa da Vlada bulunamadı ve suikast gerçekleştirildi. Bu noktada, Ustasha'nın İtalya tarafından desteklendiği, yine İtalya tarafından desteklenen IMRO'nun Ustasha ile müttefik olduğu düşünülürse bu durumun İtalyan planlarına da önemli bir darbe vurduğu anlaşılacaktır ki zaten bundan büyük rahatsızlık duyan İtalya suikast için başkalarını yönlendirecektir. Oysa Yugoslavya için gelişmeler sevindiriciydi. Zaten kral I. Aleksander da, kısa bir süre sonra gerek Bulgaristan'ın Balkan Antantı'na dâhil olabilmesi, gerekse de iki devlet arasındaki sorunların çözümü için Eylül 1934'te Sofya'ya bir ziyaret gerçekleştirdi. Oldukça parlak geçen ziyarette kral I. Aleksander tam bir "barış adamı" ilan edilmişti (BCA, 30.10.0.0/242.634.4 (9 Haziran 1934); Graham 1938, 212-215). Şimdi Fransa’ya, Marsilya’ya gidilebilirdi.

\section{Marsilya Suikastı ve Kral I. Aleksander'ın Öldürülmesi (9 Ekim 1934)}

Kral Aleksander ve eşi kraliçe Marie, Fransa Cumhurbaşkanı'na resmi ziyarette bulunmak üzere 4 Ekim 1934 gecesi saat 23.00'da Belgrat'tan yola çıktı. 6 Ekim gecesini Zelenike'deki Dubrovnik Kruvazörü’nde geçiren kral ve kraliçe, 7 Ekim sabahı Fransız donanmasından üç destroyerin eşlik ettiği Dubrovnik Kruvazörü ile Marsilya'ya gitmek üzere Yugoslav sularından ayrıldı (Akşam, 7 Teşrinievvel 1934, 2). 6 Ekim'de Paris'ten Marsilya'ya doğru yola çıkan suikastçılar ise 8 Ekim'de Marsilya'nın bir şehir planını alarak önce keşif yapmışlar, ardından kralın ziyaretine ilişkin resmi program ile rehberi edinmişlerdir (Graham 1938, 17, 20).

9 Ekim günü öğleden sonra Marsilya'da Fransız Dışişleri Bakanı Louis Barthou tarafından karşılanan kral I. Aleksander, Borsa Meydanı'nda araba ile halkın önünden geçerken kalabalık içerisindeki Makedonyalı bir Bulgar tarafindan saat 16.20 civarında açılan ateş sonucunda karnından ve kalbinden vurularak öldürülmüş, bir general ile birlikte suikast sırasında ağır yaralanan Dışişleri Bakanı Barthou da yine hayatını kaybetmiştir (Akşam, 10 Teşrinievvel 1934, 1; 11 Teşrinievvel 1934, 8). Ülkesinde "Veliki Kral Uyedinitel" (Birleştirici Büyük Kral) olarak anılan ve öldürüldüğünde 45 yaşında olan (Şimşir 1996, 277-278, 418. Aslında kral Aleksander’a "Kahraman ve birleştirici" unvanları ölümünün ardından 11 Ekim 1934 tarihinde Yugoslav Meclisi'nin oy birliği ile aldığı karar neticesinde verilmiştir; Cumhuriyet, 12 Teşrinievvel 1934, 5) I. Aleksander'ın son sözlerinin "Yugoslavya'yı muhafaza ediniz" olduğu belirtilmektedir (Cumhuriyet, 11 Teşrinievvel 1934, 7; Hâkimiyeti Milliye, 11 Birinci teşrin 1934, 1; Morawski 2016, 53.). Ayrıca kralın Fransa ziyareti için Marsilya'ya geleceğini çok önceden bilen ve yollarda hazır bir şekilde görüntü almak için bekleyen pek çok basın mensubu suikastı saniye saniye takip edip, resim ve video ile kayda almıştır. Özellikle suikastı filme alan kişinin sinemac1 Daskom olduğu belirtilmektedir (Zaman, 14 Teşrinievvel 1934, 7; Zaman, 15 Teşrinievvel 1934, 2; Akşam, 15 Teşrinievvel 1934, 1; Hâkimiyeti Milliye, 17 Birinci teşrin 1934, 1, 7).

Suikasta şahit olanların bildirdiğine göre her şey birkaç saniyede gerçekleşmişti. Katilin bu kadar kısa sürede kalabalığın içinden çıkarak araca ulaşması, hatta kurbanlarına silahının namlusunu gögüslerine temas ettirecek derece yaklaşıp on el ateş etmek suretiyle eylemini gerçekleştirmesi ise bu konuda yoğun bir eğitim aldığının kanıtı olarak değerlendirilmiştir (Morawski 2016, 51-52).

Kralın cenazesi, 14 Ekim sabahı Dubrovnik Kruvazörü ile Split Limanı'na getirildiğinde yaklaşık yüz bin kişilik kalabalık krallarına saygı için limanda toplanmıştı (Morawski 2016, 61). Yine, tren yoluyla Belgrat'a getirilirken ortaya çıkan kortej şaşırtıcı derecede kalabalıktı. Dalmaçya kıyılarından Bosna-Hersek'e, oradan Zagreb ve Belgrat'a kadar uzanan demiryolu hattı boyunca trenin durduğu her istasyona yüzbinlerce Yugoslavyalı akın etmiş, gözyaşları içinde krallarına sevgilerini göstermişlerdi (Armstong 1935, 219; Akşam, 17 Teşrinievvel 1934, 4). Suikastın ardından bir açıklama yapan Sloven muhalefet lideri Anton Koroseç’in; "Yugoslav 
ulusunun tamamının büyük kralın ölümüne yas tuttuğu bir zamanda, her şeyi unutmak gerekir. Yugoslavya için yaşamak ve çalışmak zorundayız" (Morawski 2016, 64) şeklindeki sözleri yine krala duyulan saygıyı göstermesi açısından anlamlıdır. Hakikaten kralın son sözleri, uğruna hayatını kaybettiği bir emeli ortaya koyuyordu; birleşmiş ve kaynaşmış bir Yugoslavya. Ülke içerisinde gerçekleştirdiği nispi reformlar, dış politikada izlediği uzlaşmacı ve barışçıl politikalar, yaşanılan dönemde hem yeterli görülmemiş hem de tam idrak edilememiş, dahas1 1929'da anayasayı askıya almasının ardından diktatör ilan edilmişti (Kral I. Alexander'ın uygulamaları diktatörlük olarak değerlendirilirken dört ana gerekçe ortaya konulmaktadır. İlki, 6 Ocak 1929'de 1921 Anayasası ile birlikte temel hürriyetleri de ortadan kaldıran "Kararname"yi yayımlamasıdır. Her ne kadar yetkililer tarafından, yaşanan mevcut gelişmeler karşısında son çare olarak böyle bir yola başvurulduğu ve en kısa sürede tekrar eski düzene geçileceği belirtilse de yine de bu kararname ile diktatörlük rejiminin kurulduğu ifade edilmiştir. İkinci önemli gerekçe, Sırp-Hırvat-Sloven Krallığı şeklindeki devlet isminin Yugoslavya biçiminde değiştirilmesi ve ülkenin tarihi, etnik-dini yönlerden belirlenmiş olan yer adlarıyla (Hırvatistan, Bosna, Dalmaçya gibi isimlerin), idari taksimatının değiştirilerek yerine tamamen suni ve keyfi isimlendirmelerle yeni idari sınırların çizilmesi, böylelikle idari bölümlenmenin yeniden yapılandırılmasıdır. Üçüncüsü, 4 Temmuz 1930'da alınan ve yeni rejime geçiş süreci olarak tanımlanan karardır. Öyle ki, bu karar, eski vilayetlerle birlikte tüm siyasi partilerin de kapatıldığının, bir daha da açılmasına izin verilmeyeceğinin Manifestosu olarak kabul edilmiştir. Sonuncusu ise 3 Eylül 1931'de ilan edilen yeni anayasadır. Böylelikle kontrolü eline alan I. Aleksander'ın, kısa sürede düzeni sağlayıp tekrar eski demokratik kurum-kuruluş-sistemin yerine yenilerini koymas1 gerekirken, tam tersi kontrolü altındaki ülkeyi Polis Devleti haline getirdiği ifade edilmiştir (Söz konusu gerekçelerin ayrıntılı açıklamaları için bk. Seton-Watson 1932, 23-34. Ayrıca 1931 Anayasası hakkında bilgi veren Belgrat Elçiliği'nin raporu için bk. BCA, 30.10.0.0/251.692.8 (4 Ekim 1931)). Buna karşın cenaze töreninde ortaya çıkan manzara, üstelik bir muhalefet liderinin beyanatı, Yugoslav halkının geç de olsa krallarının yapmak istediğini anladığını, istenilen birleşme/kaynaşmanın aslında hiç de farkına varılmadan gerçekleşmiş olduğunu göstermiştir. kralın ölümü ile artık ortada Sırp, Hırvat, Makedon, Sloven kalmamış tüm beyanat ve hissiyatlar Yugoslavlık bilinci etrafında birleşmiştir.

Suikast, sadece ülkedeki tüm farklı unsurları kralın şahsında birleştirmekle kalmamış aynı zamanda tüm Yugoslavların tepkisini de çektiğinden bazı istenmeyen olaylar yaşanmıştır. Zagreb'de halk suikastın azmettiricisi olarak gördüğü İtalyanlara ait ticarethaneye saldırmış, Macaristan'a karşı gösteriler tertip etmiş, Ljubljana'da İtalyan konsolosluk binasının camları kırılmıştır. Saraybosna'da da İtalyanlar ve Hırvatlar aleyhine benzer gösteriler düzenlenerek Nepredak ismindeki Hırvat cemiyeti binası ile İtalyan konsolosluğu taşlanmış, polis olaylara karşı güvenlik tedbirleri almak zorunda kalmıştır. Asiek'te ise Urvatski List adındaki Hırvat gazetesi basılmıştır (Zaman 13 Teşrinievvel 1934, 1-2; Akşam 13 Teşrinievvel 1934, 2).

Cenaze, 18 Ekim 1934 tarihinde Belgrat'a otomobille iki saat mesafedeki Karageorgeviç Hanedanı'nın mezarının bulunduğu Topola Kasabası'na götürülmüştür. Kral, hayatta iken burada gösterişli bir kilise yaptırmış ve babası ile büyük-büyükbabasının mezarlarını kilise içinde ayrılan kısma naklettirmiş, kendisi için de bir yer hazırlatmıştı. Neticede vasiyeti gerçekleştirilerek atalarıyla birlikte aynı yere defnedilmiştir (Us 1936, 7-8; Morawski 2016, 63-64).

1899 Zagreb doğumlu (Graham 1938, 234; Hâkimiyeti Milliye, 10 Birinci teşrin 1934, 1) olan ve olay sonrası intihar etmek isteyen suikastçı ise buna firsat bulamadan bir görevli tarafindan bıçaklanarak öldürülmüştür. Suikastçı, IMRO adı verilen “İç Makedonya İhtilal Komitesi” "nin eski bir üyesi idi. Ustasha'nın Hırvat üyelerinden olan üç de suç ortağı bulunuyordu. Yapılan 
tahkikatlar neticesinde suikastın, İtalya'da bulunan Ante Paveliç liderliğindeki Hırvat ayrılıkçıların örgütü Ustasha'nın bir uzantısı tarafından gerçekleştirildiğine kanaat getirilmiştir (Akşam, 17 Teşrinievvel 1934, 1, 2, 4; Güveloğlu 2015, 255; Morawski 2016, 55, 68).

Bu noktada kral Aleksander'ı öldüren suikastçının, az önce belirtildiği gibi, Ustasha ile müttefiklik kuran IMRO'nun eski bir üyesi olup, Macaristan'1n Janka Puszta kentindeki kampta terörist eğitmeni olarak çalışan, IMRO lideri Ivan Mihailov'un da şoförlüğünü yapan Vlada Gheorghieff Kerin olduğu belirlenmiştir ("Vlado Georgief Chernozemsky" şeklinde de belirtilmektedir; Armstong 1935, 221-222; Graham 1938, 251; Morawski 2016, 55-56). Bu adam daha önce 1926'da Sofya'da Bulgar siyasetçi-gazeteci Dimov'u öldürmüş, ikinci siyasi cinayetini ise 1931 'de işlemişti. Yakalanıp hapsedilmesine karşın 1932'de affedilmiştir. Bunun üzerine Macaristan'a giden Vlada Gheorghieff, burada Makedon ve Hırvat ayrılıkçı hareketlerle bağlantı kurmuştur (Seton-Watson 1935, 27). Zaten Ustasha'nın Hırvat üyelerinden olup suikasta karışan Zvonim Pospicil, Ivan Ragiç ve Mio Kralj adlarındaki üç suç ortağı da yakalanarak tutuklanmıştır (Bu kişilerin isimleri "Zvonimir Pospisil”, "Ivan Rajic” ve "Mijo Kralj” olarak da yazılmaktadır (Güveloğlu 2015, 257; Morawski 2016, 68, 71). Bunlardan, daha önceki birçok suikastta da ismi geçen Kerin'in; şimdiye kadar farklı pek çok takma ad kullandığı, hatta olaydan sonra üzerinde çıkan pasaportta Kelemen isminin geçtiği görülmüştür (Viada Gheorghieff Kerin (Vlado Chernozemski)'in kullandığı isimler; Georgief, Stoyanof, Dimitrof, Chernozemsky, Suk, Kerin, Kelemen, Velitchko olarak belirtilmektedir (Bk. Graham 1938, 1). Zagreb'deki Çekoslovakya Konsolosluğu'ndan aldığı sahte pasaportla Fransa'ya giriş yapan katil, 29 Eylül 1934 tarihinden itibaren Paris'te kalmış, bir süre sonra Marsilya'ya geçmiştir. Suikast günü katilin yanında suikastta kullandığı yarı otomatik Mauser silahtan başka bir de Walther marka tabancası bulunduğu, ayrıca iki bomba, pusula ve 1.700 Fransız Frangı para taşıdığı tespit edilmiştir (Akşam 13 Teşrinievvel 1934, 1-2; Morawski 2016, 55-56).

Tüm bunlara rağmen Fransa'nın mevcut gelişmelere yaklaşımı oldukça ilginçtir. Keza, Fransız Hükümeti'nin baskıları neticesinde kraliçe Marie mahkemeden çekilme kararı almış, Fransa Dışişleri Bakanı Barthou'nun yerine atanan yeni bakan Laval da Marsilya Suikastı'nı sessizce kapatmaya çalışmışır. Üstelik bu dönemde başlayan Fransa-İtalya yakınlaşması nedeniyle suikastın sorumlusu olarak Macaristan gösterilmiştir (Güveloğlu 2015, 257). Bu yüzden Yugoslavya ve Küȩük İtilaf (Antant) devletleri önce Macaristan'a karşı ortak bir tavır almış, sonra da Yugoslavya Macaristan'1 resmen Milletler Cemiyeti'ne şikâyet etmiştir. Bu durum Macaristan'da ilişkilerin savaşa kadar gidebileceği korkusunu yarattığı için hükümetin her türlü ihtimale karşı bir seferberlik hazırlığına başladığı söylentileri çıkmaya başlamıştır. Milletler Cemiyeti ise suikasta ilişkin soruşturma açılarak sorumluların bulunup cezalandırması gerektiği yönünde karar aldığından Macaristan derhal tahkikat başlatmıştır. Tam bu esnada bir açıklama yapan Macaristan Başbakanı; soruşturma neticesinin menfi olacağını çünkü Macaristan'da suikasttan sorumlu herhangi bir kimsenin bulunmadığını, bu meselenin de bir daha Milletler Cemiyeti gündemine gelmeyeceğini bildirmiştir (BCA, 30.10.0.0/221.491.17 (22 Ocak 1935)). Burada özellikle Macaristan Başbakanı'nın henüz soruşturmanın yeni başladığı tarihlerde verdiği beyanatın dikkat çekici olduğu belirtilmelidir. Macaristan'da pek çok Ustasha kampı bulunmasına ve faillerin de bu kamplarla yakın temas halinde olmasına karşın Macaristan Başbakanı'nın ülkesinde suikastla ilgili herhangi bir sorumlunun bulunmadığına dair garanti vermesi adeta soruşturmanın ne şekilde tecelli edeceğini peşinen ortaya koymaktaydı.

\section{Türkiye-Yugoslavya İlişkileri ve İki Liderin Dostluğu}

I. Balkan Savaşı ile I. Dünya Savaşı'nda Osmanlı Devleti'ne karşı bizzat savaşmasına karşın Milli Mücadele Dönemi'nde Yunanlıların üstlendiği rolü İngilizlerin Sırplardan da istemesi, an- 
cak I. Aleksander'ın buna karşı çıkması, aslında iki ülke arasındaki ilişkilerde bir kırılma noktası olarak değerlendirilebilir. Zira İngiliz Başbakanı David Lloyd George, Sırp-Hırvat-Sloven Krallığı Hükümeti'ne gönderdiği telgrafta, Sırpların Anadolu'ya asker çıkararak Türklerle savaşmaları teklifinde bulunmuştur. Hükümet Başkanı Nikola Pasiç, I. Aleksander ile yaptığ1 görüşme sonrası verdiği cevapta; Sırplar ile Türklerin daha 1912'de kendi hesaplarını kendi aralarında çözümlediğini, o andan itibaren bu iki milletin ancak dost olabileceğini belirterek teklifi geri çevirmiştir. Üstelik benzer bir teklifi Romanya'ya da yapan Lloyd George, I.Aleksander'in tavsiyesini dinleyen Romanya'dan da olumsuz yanıt almıştır. Hatta Nikola Pasiç, İngiltere’ye ret cevabını gönderirken, aynı zamanda Lloyd George ile I. Aleksander'a haber vermeksizin Mustafa Kemal Paşa'ya da durumu açıklayan bir bilgilendirme telgrafı göndermiştir (Karahasan 1994, 2540-2541).

Ancak aynı Sırp-Hırvat-Sloven Krallığı, hissesine düşen Osmanlı borçlarını ödemek istemediğinden Lozan Barış Antlaşması'nı imzalamamış, dolayısıyla Türkiye ile resmi ilişkiler hemen kurulamamıştır. Gayr-i resmi boyutta başlayan ilk ilişkiler ise ağırlıklı olarak soğuk ve gergin bir atmosfer içerisinde sürdürülmüştür (Özgiray 1999, 11-12; Şimşir 1996, 404). Nihayet, 28 Ekim 1925 tarihli Barış ve Dostluk Antlaşması'nın imzalanması ile resmen 1 Kasım 1914 'ten bu yana devam eden savaş hali sona erdi. İlişkiler ancak bu tarihten itibaren normalleşme sürecine girdiği için ilk olarak karşıllklı elçiler atandı. 22 Ağustos 1925'de Belgrat'a gönderilen Yusuf Hikmet Bey (Bayur), Şubat 1926'da elçi olarak güven mektubunu sundu. Ankara'ya gelen ilk Sırp-Hırvat-Sloven Krallığı Elçisi Thomir Popoviç de 21 Temmuz 1926'da Gazi'ye güven mektubunu verdi (Soysal 2000, 90-91, 256; Şimşir 2001, 259-262; Güveloğlu 2012, 147-148,151-153). 1929 yılına kadar krallık sınırlarında kalan Türk/Müslüman ahalinin emlâk1 sorunu, borçların ödenmesi meselesi gibi sıkıntıların çözümü konusunda bazı önemli adımlar atıldı. 1932 yılından itibaren de Türkiye ile Yugoslavya arasında imzalanan çeşitli antlaşmalarla sıcak ilişkilerin geliştirilmesine çalışıldı (Özgiray 1999, 19-20; Soysal 2000, 256). Böylelikle her iki ülke lideri, diğerini destekler nitelikli politikalar izlerken aynı zamanda aleyhlerinde yaşanan her türlü gelişmeyi takip eder oldu. Londra'da, Yugoslavya kralı I. Aleksander aleyhine bir suikast hazırlı̆̆ 1 olduğunun belirlenmesi üzerine faillerin faaliyetlerini Londra'dan Avrupa içlerine kaydırdıkları hakkındaki bilginin elde edilmesinden hemen sonra 14 Aralık 1932'de Ankara'ya bildirilmesi bunu gösteriyordu (BCA, 030.10.00.00/251.695.1 (4 Ocak 1933)).

Tüm bu olumlu gelişmelerin bir sonucu olarak kral I. Aleksander, eşi Marie ile birlikte, Romanya ve Bulgaristan ziyaretlerinin ardından ülkelerine deniz yoluyla dönerken, 4 Ekim 1933 'te İstanbul'a gelmişlerdir. Şüphesiz ziyaretin asıl nedeni, Balkanlarda huzur ve asayişi tesisi edecek bir Balkan Antantı'nın kurulmak istenmesiydi.

Ancak gerek kraliçe Marie’nin Romanya kraliçesi olan annesi ile birlikte 4-11 Mayıs 1932 tarihleri arasında İstanbul'a yaptıkları bir haftalık gezi ve bu gezide kendilerine gösterilen ilgi ve alakay1 kocasina aktarması (Bk. BCA, 30.10.0.0/246.667.2 (21 Mayıs 1932); BCA, 30.10.0.0/251.694.6 (28 Mayıs 1932); Şimşir 2001, 278-279), gerekse de kralın Gazi Mustafa Kemal Paşa hakkındaki;

"Şüphesiz ki Reisicumhurunuz devrimizin dikkate en laylk simasıdır. Teşkilatçı, idareci ve Islahatçı olarak vücuda getirdiklerine hayranım. Bir de buna bir asker sıfatı ile askeri iktidarına ayrıca hayran olduğumu ilave etmeliyim. Her sahada olduğu gibi bir de Ankara'da büyük bir imar gayreti cereyan ettiğini biliyorum. Hâlbuki orada toprak ve iklim o kadar müsait değilmiş. Beis yok; Gazi Hazretleri muhasım insani anasıra 
karşı olduğu gibi tabiatın muhasım anasırına karşı da muvaffak oluyorlar" (Şimşir 2001, 282).

şeklindeki düşünceleri kralın İstanbul ziyaretinde etkili olmuştur. Öyle ki kral cümlelerini; "İstanbul'da kendileri ile görüşebilmek beni bahtiyar edecektir." (Şimşir 2001, 282) biçiminde bitirecektir. kralın sözleri, kendisine aktarılan izlenimler ile bilgilerin bir tezahürüydü ve kralı, barış ve güvenliği kendine düstur edinip gelişme yolunda ülkesini gerçek bir dönüşüme uğratan Gazi hazretleri ile tanışmaya sevk etmişti. Böylesi ilerici bir liderle ortak hareket ederek Balkanlarda güven ve barış ortamını pekâlâ tesis edilebilirdi.

Kralın ziyareti, henüz İstanbul'a gelmeden önce Yugoslav basınında özellikle siyasi gelişmeler bağlamında geniş yankı uyandırmıştı. 2-3 Ekim'de Belgrat Elçiliği'nden gönderilen raporların aktardığı kadarıyla, Yugoslav basınının bir nezaket ziyaretinden ziyade son yılların en önemli olayı olarak değerlendirdiği ziyaret, Balkanlar ve Akdeniz havzası için son derece önemli sonuçlar doğuracaktı. İki liderin görüşmesi neticesinde açılan diyalog yolunun sadece Balkanlarda değil tüm Avrupa'da barış ve güvenliği korumaya yardımcı olacak bir Balkan ittifakının kurulmasına yönelik beklentileri artırdığı ifade edilmiştir (BCA, 30.10.0.0/200.366.22 -1 (4 Ekim 1933); Şimşir 2001, 287-289).

Ayrıca Türk Dışişleri Bakanlığı, Yugoslavya kralı I. Aleksander'ın İstanbul ziyaretini Moskova'ya bildirerek, Sovyet Hükümeti'nin bu ziyareti nasıl telakki edeceğinin öğrenilmek istendiği belirtilmiştir. Yine kralın seyahati, İstanbul'daki ikameti ve Cumhurbaşkanı Mustafa Kemal Paşa ile olan görüşmeleri hakkında daha sonra tekrar bilgilendirme yapılacağı ifade edilmiştir (Şimşir 2001, 280). Türkiye'nin Sofya Elçiliği'nden gönderilen bir raporda ise yapılacak ziyaretin İtalyan kamuoyunda olumsuz şekilde değerlendirildiği, Yugoslavya ve Romanya ile kurulan iyi ilişkilerin, Bulgaristan'ı yalnız bırakmak gayesi ile bilinçli bir şekilde Türkiye tarafından gerçekleştirildiği düşüncesinin hâkim olduğu aktarılmıştır (BCA, 30.10.0.0 /200.366.22-2 (4 Ekim 1933)). Görüldüğü üzere Türkiye, Yugoslavya ile sıcak ilişkiler kurarken sadece ikili münasebetlere yoğunlaşmamış, uluslararası dengeleri gözeterek bir yandan Sovyet Rusya'nın tavrı ögrenilmeye, diğer yandan da İtalya kamuoyu takip edilerek milli menfaatler çerçevesinde çok yönlü bir dış politika izlenilmeye çalışılmıştır.

Cumhurbaşkanı Gazi Mustafa Kemal'in konuğu olarak Dolmabahçe Sarayı'nda ağırlanan kral, İstanbul'da itinalı bir şekilde misafir edilmiştir. Şehrin baştan aşağı Türk ve Yugoslav bayraklarıyla donatıldığı ziyaret esnasında, Türk halkı Yugoslavya kralına büyük sevgi ve tezahürat gösterilerinde bulunmuştur (Geniş bilgi için bk. Erden 2006, 19-23).

İlk kez Dolmabahçe Sarayı'nın rıhtımında bir araya gelen kral ve gazi, Dolmabahçe Sarayı'na geçerek ilk samimi ve resmi görüşmelerini burada gerçekleştirdi. Yaklaşık yarım saat süren görüşmede; kral I. Aleksander, Varna'da Bulgar kralı Boris ile yaptığı mülakat hakkında kısa bir bilgi verdikten sonra Balkanlarda her bir devletin bir diğerinin toprak bütünlügüne sayg1 duyup, bir arada yaşayabileceği gerçek bir huzur ve güven ortamının kurulabilmesi için mutlaka Türkiye ile işbirliği yapmak istediğini belirtti. Dahası, bunun sağlanabilmesi için iki taraf arasında o gün için en önemli sorun olan emlak meselesinin çözümü için gerekli talimatları verdiğini bildirdi (Emlak sorununun çözümüne ilişkin talimat Haziran 1930'da verilmiştir (Bk. BCA, 30.10.0.0/250.691.22 (18 Haziran 1930)). Karşılığında Mustafa Kemal Paşa, Türkiye ile Yunanistan arasında imzalanan antlaşmanın barışın tesisi için yapıldığını, Balkanlarda istenilen istikrar için teklif edilen işbirliğini de memnuniyetle kabul ettiğini açıkladı. Böylece Balkanlarda barışın korunması amacıyla Balkan devletlerinin kendi aralarında iyi ilişkiler kurup birlikte çalışılması gerektiği konularında aynı fikirde olunduğu anlaşı1dı (Atatürk'ün Milli Dış Politikası 1994, 225-226; Şimşir 1981, 177-178). Artık Türkiye ve Yugoslavya, belirtilen amaçlar 
doğrultusunda birlikte çalışmaya karar vermişti.

Görüşmenin ardından eşi ve refakatindekilerle birlikte İstanbul'u gezen kral, akşam tekrar Dolmabahçe Sarayı'na gelmiş ve Gazi ile siyasi mevzulardaki sohbetlerine gece yarısına kadar süren yemek ziyafetinde devam etmişlerdir. Böylelikle başta Balkan Antantı olmak üzere ana hatlarıyla üzerinde anlaştıkları tüm konularda kesin bir uzlaşmaya varmışlardır (Şimşir 1981, 178-179).

Her iki görüşme, siyasi konuların yanı sıra yakın bir dostluğun başlangıcını teşkil edecek sohbetlere de vesile olmuştu. I. Aleksander, dostluğunu kaybetmek istemediği Mustafa Kemal Paşa'dan kendisini “asker arkadaşlı̆̆ı"na kabul etmesini istemiştir (Şimşir 1981, 179). Teklifin verdiği samimiyet sohbetin de derinleşmesine sebep olduğundan yine kral, Mustafa Kemal Paşa'ya bir sırrını/anısını anlatmak ihtiyacı hissetmiş ve; "Eğer bazı Avrupa devletlerinin vaatlerinde inanmış olsaydık, Yunanlıların yerine Anadolu'ya biz çıkacaktık" demiştir. Bunun üzerine kralın elini sıkan Gazi; "Öyleyse geçmiş olsun demeliyim Ekselans” şeklinde cevap vererek, Yugoslav kralı ile halkının böylesi bir hataya düşmemekle, Yunanlılarınkine benzer bir mağlubiyetten kurtulduklarını hatırlatmak istemiştir (Erden 2006, 25-26; Lord Kinross 2007, 531).

Kral I. Aleksander'ın aktardığı sır, -yukarıda bahsedildiği üzere- Hükümet Başkanı Nikola Pasiç’in krala danışmasının ardından İngiltere'ye gönderdiği ret cevabı idi. Ancak burada belirtilmelidir ki, kral bu olayı, Mustafa Kemal Paşa'nın İngilizlerin talebinden haberinin olmadığını düşünerek aktarmıştır. Oysa Paşa, Nikola Pasiç tarafından gönderilen bilgilendirme telgrafı ile tüm gelişmelerden haberdardı. Burada durumdan habersiz olan ve bunu sır olarak sakladığını düşünen kişinin kral I. Aleksander olduğu ortaya çıkmaktadır.

Akşamki ziyafetin ardından başlayan poker partisinde ise gazi ile kral karşı karşıya yer almışlardır. Oyun esnasında eline üç yedili gelen gazi; “Açtım” deyip krala dönerek, "Siz de iştirak ediyor musunuz?” diye sorunca kral, "Her zaman sizi takip ederim" şeklinde cevap vermiştir (Erden 2006, 26). Artık gaziye bir kahramana duyulan hayranlıkla bağlanan kral, ileride çıkacak bir savaş durumunda onun emirlerine bir er gibi boyun eğeceğini dahi belirtmiştir (Kinross 2007, 531). Söz konusu yanıtlar, gazi ile kral arasındaki ilişkinin ne kadar yakın ve samimi bir boyuta ulaştığını, ayrıca kralın, ülkesini ve milletini kalkındırıp ilerlemesi adına her şeyi göze alan gaziyi örnek aldığını gösteren en güzel ifadelerdir.

Gecenin sonunda Yugoslav kralı ile kraliçesi, gemilerine binerek Korfu'ya doğru yola çıktı. Böylece Yugoslavya kralı I. Aleksander'ın hayatındaki ilk ve son Türkiye ziyareti sona erdi. Misafirlerin gitmesinin ardından, "Kral'ı nasıl buldunuz?" sorusunu yönelten arkadaşlarına Gazi; "Çok nazik, çok zeki bir adam. Memleketi için çalışmış, çalışlyor. Makûl görüşlü... Kendisini çok beğendim” (Gürkan 1971, 104) diyerek, kral'ın kendisi için hissettiği duyguları, aynı şekilde kendisinin de krala karşı hissettiğini ortaya koymuştur.

Kralın ülkesine döndükten sonra Gazi hakkında Bükreş Elçisi Çolak Antiç'e sarf ettiği sözler, Antiç tarafindan Türkiye'nin Bükreş Elçisi Hamdullah Suphi’ye nakledilmiştir. Buna göre kral, gazi hakkında aynen;

"Hali, tavrı, konuşması, başı, bakışı ve sesi derhal insan üzerinde nadir bir adam karşısında bulunduğumuzu düşündüren bir tesir bırakıyor. Bu mülakattan bahtiyar döndüm. Devrin bu faik adamı ile anlaşmanın kolay olacă̆ına dair bir intiba hâsıl ettim. Çok derin görüşü, çok vazıh düşünüşü, tereddütsüz karar vermeğe müsait olan muhakemesi Balkan milletlerinin anlaşması sahasında bize ne kadar faideli olacaktır, anladım. Kendisinden ayrıldığım vakit onu çok sevdiğimi ve ona bağlandı̆̆ımı 
hissetmiştim" (BCA, 030.10.00.00 / 251.696.22 (25 Kasım 1933)).

ifadelerini kullanmıştı. $\mathrm{Bu}$ ise kralın gaziye karşı gerçekten samimi dostluk bağlarıyla bağlandığını, ayrıca Gazi’yi sadece iki devlet arasındaki ilişkilerde değil tüm Balkanların geleceği konusunda fikri ve desteği alınması gereken bir lider olarak gördüğünü ortaya koymaktadır.

Bu sıcak ilişkilerin bir sonucu olarak, iki ülke arasında 27 Kasım 1933’te Belgrat’ta, “Türkiye-Yugoslavya Dostluk, Saldırmazlık, Yargısal Çözüm, Hakemlik ve Uzlaştırma Andlaşması”" imzalanmış (Soysal 2000, 450-454), 9 Şubat 1934'te de Türkiye, Yugoslavya, Yunanistan ve Romanya arasında Balkan Antantı yapılmıştır. Ancak kral I. Aleksander, İstanbul ziyaretinden tam bir yıl, pakt antlaşmasının imzalanmasından ise sadece on ay sonra suikasta maruz kalmıştır.

\section{Suikastın Türkiye'de Duyulması ve Devlet Erkânı}

Yugoslavya kralı I. Aleksander'ın varlığı nasıl iki ülke arasındaki dostluğun oluşup kaynaşmasını sağladıysa, Marsilya Suikastı ile hayatını kaybetmesi de o derece Türk devlet erkânı ile milletini derin üzüntüye boğmuştur.

I. Aleksander'ın ölüm haberi, Türk devlet ricali tarafından aynı gün öğrenilmesine karşın tüm ülkeye ilk olarak 10 Ekim 1934 tarihinde çıkan gazetelerle duyurulmuştur. İlk sayfalarının neredeyse tamamını Marsilya Suikastı'na ayıran Türk basını, verdiği bilgilerin ardından Yugoslav Hükümeti ile halkına taziyelerini sunmuştur (Bk. Akşam 10 Teşrinievvel 1934, 1; Hâkimiyeti Milliye, 10 Birinci teşrin 1934, 1; Zaman 10 Teşrinievvel 1934, 1; Cumhuriyet 10 Teşrinievvel 1934, 1).

Suikast, tüm ülkede olduğu gibi Ankara'da da büyük bir şaşkınlıkla karşılandı ve bütün devlet kurumları ile halkta derin bir üzüntüye sebep oldu. Ancak bunlar içerisinde şüphesiz en fazla üzüntü duyanı Gazi hazretleriydi. "Kardeş" nazarında baktığı "asker arkadaşını" kaybetmişti.

Gerçekten de kral I. Aleksander, Türkiye’nin ve gazinin dostuydu. Daha bir yıl önce Türkiye’ye gelmiş ve Balkanlarda kalıcı bir barışın kurulması için Gazi ile sözleşmişlerdi. On ay önce ise Türkiye, Yugoslavya, Yunanistan ve Romanya arasında imzalanan Balkan Antantı'nın temelini atmışlardı. kral ve gazi Balkanlardaki barış ve huzurun iki ayrı mihenk taşı olduğundan her iki lider de Balkan politikalarında birbirlerinin sarsılmaz destekçileriydi. Bu nedenle suikast haberi, gaziyi ve onun hükümetini derinden sarstı.

Şükrü Kaya'dan aktarmak suretiyle Hasan Rıza Soyak anılarında şöyle demektedir;

“Hatırlarım; Yugoslavya kralı Aleksander'ın Marsilya'da öldürüldügünü haber alır almaz, hemen Atatürk'ün yanına koştum. Başvekil ile Dışişleri Vekili de oradaydılar. Atatürk, kralın öldürüldüğünü öğrenmişti; çok müteessirdi:

"Ben, Aleksander'ı öldürenleri biliyorum, eğer onlar firsat bulurlarsa beni de öldürürler" dedi.

Vukuu muhtemel hadiseler mütalâa edilirken, Atatürk, Yugoslavya'nın müdafaası icap ederse, şimdiden seferberliğe tevessül edileceğinin taziye telgrafinda bildirilmesini istemişti” (Soyak 2014, 505-506).

Hemen akabinde gazi, kral I. Aleksander'ın oğullarından prens Paul, prens II. Pierre ve kraliçe Marie'ye birer taziye telgrafı göndermiştir. Kral hazretlerine yapılan vahşiyane suikast haberini büyük bir teessürle haber aldığını ve sadık bir dostu, aynı zamanda samimi bir kardeşi olmaktan gurur duyduğu büyük kralın vefatı nedeniyle Yugoslavya'nın duyduğu acıyı bütün Türk milletinin de aynı şiddette hissettiğini belirten gazi, kral ile Yugoslavya'nın bir dostu sıfatıyla en samimi taziyelerini sunarak telgraflarına son vermiştir (Akşam 10 Teşrinievvel 1934, 4; Hâki- 
miyeti Milliye, 10 Birinci teşrin 1934, 1-2; Şimşir 2001, 314-316).

Gazi'nin gönderdiği başsağlığı telgraflarına Yugoslav basını; "Müteveffa kral Aleksander'ın hudutsuz dostu olan Gazi Mustafa Kemal, kral Aleksander'ın mensup olduğu kabiliyet ruhunun ailesine mensup bulunmaktadır. Ruhen ve vicdanen asil olan gazi, kralımıza kardeşçesine acımıştır. Mustafa Kemal'in taziyesinde memleketimiz, genç kralımız ve onun milleti hakkında istimal edilen sözler, 10 Teşrinievvelden sonra yaşadı̆̆ımız anların en heyecanlı bir hadisesidir” yorumunu yapmıştır (Güveloğlu 2015, 260).

Başbakan İsmet İnönü de yine 9 Ekim günü Yugoslavya Başbakanı M. Uzunoviç’e bir başsağlığı telgrafi göndererek; vahşiyane suikast haberinin kendilerinde çok büyük bir keder uyandırdığını bildirmiş, akabinde Avrupa'nın en değerli barış insanlarından birinin kaybının her cihette büyük üzüntüyle hissedileceğini ifade etmiştir. Yugoslavya milletinin matemini en içten duygularla paylaşan Türk milletinin de bu büyük Avrupalı kralın naaşı önünde eğildiğini sözlerine ekleyerek Cumhuriyet Hükümeti namına taziyelerini ilettiğini belirtmiştir (Hâkimiyeti Milliye, 11 Birinci teşrin 1934, 2; Zaman, 11 Teşrinievvel 1934, 2).

Bir gün sonra ise Belgrat Elçisi Haydar Bey, Yugoslav Başbakanı ile Dışişleri Bakanı Vekilini ziyaret ederek taziyelerini sunmuştur. $\mathrm{O}$ ana dek Türkiye'den gelen tüm samimi başsağlığ1 mesajlarından ötürü Haydar Bey'e teşekkür eden Yugoslav Başbakanı, Gazi hazretleri gibi dostluğuna güvendikleri müttefiklerine dayanarak bu acı devreyi sükûnetle geçirmeye çalıştıklarını söylemiştir. Ayrıca iki devlet arasında kral ve gazi tarafından kurulan iyi ilişkilerle ittifaka sadık kalıp aynı siyaseti devam ettireceklerinin sözünü vererek bunun Gazi ile Cumhuriyet Hükümeti'ne bildirilmesini istemiştir (Şimşir 2001, 318).

Taziye telgraflarının dışında İstanbul'daki Yugoslav ve Fransız Konsoloslukları devlet ricali tarafindan sürekli ziyaret edilmişlerdir. Taziyelerini bildirenler arasında İstanbul Valisi $\mathrm{Mu}-$ hiddin Bey, Gazi Mustafa Kemal namına Cumhurbaşkanlığı Başyaveri Celal Bey, Başbakan ve Dışişleri Bakanları adına özel kalem müdürleri yer almaktaydı (Cumhuriyet, 11 Teşrinievvel 1934, 8; Akşam, 11 Teşrinievvel 1934, 2; Hâkimiyeti Milliye, 11 Birinci teşrin 1934, 2).

Sadece başsağlığı mesajları ile yetinmeyip dostluğunu somut olarak hissettirmek isteyen Türk Hükümeti, 12 Ekim 1934 tarihinde, kralın cenaze törenine üst düzey askeri ve diplomatik yetkililerle katılma kararı almıştır. Buna göre; kral I. Aleksander'ı yakından tanıyan Dışişleri Bakanı Tevfik Rüştü Aras, Türkiye'yi temsil etmek üzere cenaze törenine gönderilecek heyetin başkanlığını yapmakla görevlendirildi. Heyette Tevfik Rüştü Aras'tan başka İkinci Ordu Müfettişi Birinci Ferik (Orgeneral) İzzetin Bey (Çalışlar), Emir Zabiti Binbaşı Ahmet Bey, Cumhurbaşkanlığı Başyaveri Binbaşı Celal Bey (Üner), Deniz Harp Akademisi Kumandanı Miralay Fahri Bey, Kaymakam Talat Bey, Hava Binbaşısı Naim Bey, Dışişleri Bakanlığı Altıncı Daire Şefi (Birinci Daire Umum Müdürü) Cevat Bey (Açıkalın), Dışişleri Bakanı Özel Kalem Müdürü Refik Amir Bey, Muhafiz Alay Komutanı İsmail Hakkı Bey ve Emniyet Memuru Sadık Efendi yer almaktayd1 (BCA, 30.18.1.2 / 48.69.1 (13 Ekim 1934); BCA, 30.18.1.2 / 51.3.19 (13 Ocak 1935); Hâkimiyeti Milliye, 13 Birinci teşrin 1934, 1-2; Şimşir 1996, 279).

Ayrıca Gazi, Cumhurbaşkanlığı Muhafız Alayı'ndan 130 mevcutlu bir askeri birliği cenaze törenine göndermiştir. Kaymakam İsmail Hakkı Bey komutasındaki bu birlikte iki yüzbaşı ve altı teğmen de bulunmaktaydı. Böylece Cumhuriyet tarihinde ilk kez bir Türk askeri birliği yabancı bir hükümdarın cenaze törenine katılmış olacaktı. Türkiye böyle bir birlik göndererek Yugoslavya’ya ve tüm dünyaya kral I. Aleksander'ın mimarlarından biri olduğu Balkan Antantı'nın yaşatılacağı, bu konuda Türkiye'nin Yugoslavya'nın yanında yer aldığı ve dayanışma içinde olunacağı mesajını vermiştir (Falih Rıfkı 18 Birinci teşrin 1934, 1; Armstong 1935, 218; 
Şimşir 1996, 279).

Gönderilen heyet ile askeri birliğin Belgrat’ta ve dünya basınında büyük yankı uyandırdığını söylemek gerekir. Belgrat’taki Türk Elçisi Haydar Aktay, "Başkumandanlarının cenaze merasimine Muhafiz Alayından bir bölük göndermek suretiyle Reisicumhur hazretlerinin büyük alakalarını gösteren bu büyük dikkati asker ruhu taşıyan Yugoslav zimandaranı üzerinde çok büyük bir tesir yapmıştır" (Şimşir 1996, 279) demektedir. Washington Büyükelçiliği'nden gönderilen bir raporda ise New York Times Gazetesi'ndeki bir makaleden bahsedilerek, birbirleriyle uzun yıllar düşman olan iki milletten Türklerin Sırp kralı için askeri bir bölüğü Belgrat'a göndermesinin fevkalade bir gelişme olduğunun, hatta bunun Avrupa'nın değiştiği anlamına geldiğinin yazıldığı ifade edilmiştir. Makalede, Cumhurbaşkanı Mustafa Kemal'in aziz dostunun hatırası için gönderdiği en iyi Türk askerleri itinayla anlatıldıktan sonra şimdiye kadar sadece savaş için karşı karşıya gelen bu iki milletin askerlerinin şimdi Balkanlarda barış ve huzurun idamesi için bir araya geldiğini belirtmiştir. Dolayısıyla bu durum da tarihin bir cilvesi olarak değerlendirilmiştir (BCA, 30.10.0.0 / 252.698.15 (19 Aralık 1934)).

Dışişleri Bakanı Tevfik Rüştü Aras, cenaze töreni için gittiği Belgrat’ta Yugoslavya'daki Politika Gazetesi'ne bazı açıklamalar yapmıştır. Buna göre Aras;

“Sizler büyük kralınız için ağlarken bizler de Gazi’nin kardeşi için ăgllyoruz...gördüklerim, kral Birinci Aleksandr Hazretlerinin hakikaten Yugoslav milletinin hiç bir zaman unutamayacağl çok sevilen bir hükümdar olduğu hakkındaki kanaatimi takviye etmiştir. Merasim müessir ve muhteșem oldu.

...

Şimdi sükûn içinde, önümüzde bizi bekleyen büyük işi düşünmemiz ve kahraman kralınız ile namdar şefim Gazi Mustafa Kemal Hazretlerinin başladıklar esere gerek sizin ve gerek bizim devam etmemiz lazım gelmektedir. Onların bu eserleri, beynelmilel teşriki mesai ve beynelmilel sulhun temini eseridir ve bizler bu işe devam edeceğiz.

Birçok muhik sebepler dolayısı ile milletlerimizin daha iyi bir istikbalde müstahak olduklarına inanmalıyı. Kahraman kralın menfur bir suikasta kurban gitmesi üzerine Yugoslavya'nın zayıflamasinı bekleyenler hayal inkisarına uğramış ve bugün iki misli olan dâhilî kuvvetinin haricî siyaseti üzerinde ve dolaylst ile Balkanların ve umumiyetle Avrupa'nın tesanüdü üzerinde tesirini gösterdiği muhteşem Yugoslavya'yı herkes hayranlıkla müşahede ve imkân bulmuştur.

Ölüm bir hakikat olmakla beraber vaziyet böyledir: kahraman kralın ölümü, Balkanlarda ve Avrupa'da vaziyetin tarsini eserine daha fazla ikdam ile devam edilmesini intaç eyleyecektir.

Nihayet kardeşinin ölümü haberi ile Büyük Şefimizin ne kadar müteessir olduğunu söylemek isterim. İstanbul mülâkatından sonra kendileri Birinci Aleksander'ı daima kardeşim diye yâd etmekte idi. Son defa da milletimize kardeşini kaybettiğini ilan eyledi ve Yugoslavya'nın ittihadını temin eden kralınızın ölümüne Türkiye'de bu suretle ağlandı.

Türk milletinin hissiyatınıza ne derece iştirak ettiğini telgraflarda da görmüşünüzdür. Fakat bunu daha iyi anlamanı için şunu söyleyeyim ki yeni Türkiye'de bu ana kadar millî matem tutulmamıştır. Kral Aleksander'ın cenazesinin kaldırıldı̆̆g gün Türkiye'nin ilk matem günü olmuştur. Maalesef kral Aleksander ölmüştür. Fakat eseri ebediyen yaşayacak ve 
bu eser, bizi Balkanlarda tesanüdün ve sulhün tahkimi yolunda müşterek işin başında ebediyen toplu bulunduracaktır...” (Hâkimiyeti Milliye, 21 Birinci teşrin 1934, 1-2).

diyerek hem Türkiye'de duyulan hissiyata tercüman olmuş hem de uluslararası politikada kralın etkinliğinden bahsederek geriye bıraktığı mirasa ne surette sahip çıkılacağının mesajını vermiştir.

Tevfik Rüştü Aras'ın yaptığı konuşma, Türkiye'nin Yugoslavya kralı I. Aleksander’a duyduğu sayg1 ve sevgiyi net bir şekilde ortaya koyarken aynı zamanda şimdiye kadar gerçekleşmeyen bir ilkin kral hazretleri için hayata geçirildiğini göstermiştir. Öyle ki Türkiye'de ilk defa kralın toprağa verildiği 18 Ekim günü milli yas ilan edilmiştir. Bu, Cumhuriyet tarihinde ilk defa yabancı bir hükümdar için milli yas edildiği anlamına geliyordu.

Kralın defnedildiği 18 Ekim günü Ankara'daki Yugoslavya Elçiliğì'nde düzenlenen merasime yine Türk Hükümeti özel bir ihtimam gösterdi. Cumhurbaşkanı Mustafa Kemal Atatürk adına Yaveri Cevdet Bey, Özel Kalem Müdür Yardımcısı Sabit Bey, Başbakan İsmet Bey ve eşi, İçişleri Bakanı Şükrü Bey, Dışişleri Bakanlığı’ndan Numan Rıfat, Ankara Valisi Nevzat Bey, Mevkii Kumandanı Sitkı Paşa ve Emniyet Müdürü Salih Bey Ankara'daki merasime katılan başlıca isimlerdir (Hâkimiyeti Milliye 19 Birinci teşrin 1934, 1; Akşam 19 Teşrinievvel 1934, 2; Zaman 19 Teşrinievvel 1934, 1).

Cenaze töreninden bir gün sonra ise Küçük Antantı oluşturan Yugoslavya, Çekoslovakya, Romanya devletleri, Balkan Antantı üyelerinden de Türkiye ve Yunanistan Belgrat'ta dışişleri bakanları düzeyinde iki toplantı gerçekleştirdiler. Yayımlanan ortak tebliğde; yabancı topraklarda planlanmak suretiyle barış antlaşmalarını bozmak ve başkanlarını öldürerek bazı devletleri zayıflatmak amaciyla gerçekleştirilen bu tür sistematik girişimlere dikkat çekilmiş ve derhal ilgili örgüt ve suçluların bulunarak cezalandırılması gerektiği belirtilmiştir. Ayrıca gerekli uluslararası önlemlerin alınmaması durumunda çok daha ciddi ve yeni sorunların çıkmasının kaçılmaz olduğunu vurgulanmıştır (Armstong 1935, 223; Graham 1938, 248; Cumhuriyet, 21 Teşrinievvel 1934, 5). Böylelikle Türkiye, kralın cenazesi dolayısıyla şimdiye kadar olduğu gibi bundan sonra da Yugoslavya'nın yanında olduğunu, daha önemlisi Balkanlar ile Avrupa'da huzur ve sükûnetin sağlanmasından hatta dünya barışının tesisinden yana olduğunu ilan etmiştir.

Tebliğ, Akşam gazetesinde; elim cinayet karşısında Balkan Antantı ülkeleriyle Küçük İtilaf devletlerinin aynı görüş ve düşüncede olduğunun, Avrupa barışını ilgilendiren her türlü meşelede birlik ve beraberlik yolunda ortak hareket edildiğinin kanıtı olarak değerlendirilmiştir. Prag'dan Ankara'ya kadar Avrupa'nın doğusunda barışı korumaya azmetmiş beş devletin, böylesi zor bir dönemde dünya kamuoyuna verdikleri itidal ve sağduyu çağrısı takdire şayan görülmüştür. Ayrıca suikastın iç veya şahsi meseleye değil, diğer ülkelerde faaliyet gösteren cenahlara dayandığı yönündeki ifadeler tebliğin en önemli kısımları olarak değerlendirilmiştir. Buna göre; suikast aslında özel değil resmi, milli değil uluslararası bir mahiyet arz ettiğinden buna cesaret edenlerin bağımsız hareket eden komiteler olduğunu düşünmek pek akıllıca değildir. Geniş siyasi teşkilatlarla yabancı devlet yardımlarına dayanmayan örgütlerin bir kişiyi öldürmesiyle istenilen netice elde edilemeyeceğine göre mutlaka bu tarz siyasi suikastlardan sonra ortaya çıkabilecek muhtemel siyasi çözülme ve kargaşalardan yararlanmayı bekleyen güçler olacaktır. Bu yüzden tebliğe imza atan devletler buna asla izin vermeyeceklerini, daha önce olduğu gibi bundan sonra da barış, istikrar ve güven istikametinde birlikte çalışacaklarını ifade ettikten sonra diğer devletlerin de bu tarz örgütlere karşı kendi içlerinde gerekli tedbirleri almaları, birbirleriyle olan ilişkilerde dostluk ve anlaşma yolunu tutup ortak hareket etmeleri tavsiyesinde bulunmuşlardır (Necmeddin Sadık, 22 Teşrinievvel 1934, 1-2). 
Benzer değerlendirmelerde bulunan Hâkimiyeti Milliye gazetesi yazarı Falih Rıfkı, farklı olarak; söz konusu beş devletten tamamının aralarından birini zayıflatmaya yönelik gerçekleştirilecek herhangi bir girişim karşısında kesinlikle ilgisiz kalmayacağına dair söz verdiklerinin altını çizmektedir. Bölgesel paktların ruhunu yansıtan bu kararın alınmasını doğru bulan Falih Rıfkı, eğer ki bölgesel devletlerin gerçek menfaati barışta ise bu devletlerden birini d1şarıdan veya içeriden sarsacak her türlü teşebbüsün, bölge güvenliğine tehdit olarak algılanması gerektiğini söylemektedir. Bu noktada, gerek iki Küçük İtilaf, gerek üç Balkan Antantı devletinin Yugoslavya için göstermiş olduğu dayanışma, Orta Avrupa ve Balkan paktlarının gizli ve menfaatkar emellerden ne kadar uzak olduğunu ortaya koymuştur. Yani tebliğdeki sözlerini, eylemleriyle dünya kamuoyuna göstererek tutarlı bir vaziyet takınmışlardır. Değerlendirmenin sonunda ise Falih Rıfkı; "Belgrat toplantıları bulanık suyu durultmuş ve Balkanlar mıntıkasını, kral Aleksander'ı mezarında ve herkesi yatağında rahat uyutacak olan bir sükûnet havasına kavuşturmuştur", diyerek Balkan Antantı ile Küçük İtilaf'ın üzerine düşeni yaptığını ifade etmiştir (Falih Rıfk1, 21 Birinci teşrin 1934, 1, 3).

Hakikaten iki farklı uluslararası siyasi örgütün, dış politikada böylesi ortak kararlar alıp, ortak cephe oluşturmaları diplomasi tarihinde bir ilk olarak değerlendirilmektedir. Çünkü siyasi teşkilatlar genellikle birbirlerine rakip olduklarından, izledikleri amaçlar da doğal olarak taban tabana zıt olurdu. Oysa burada iki uluslararası örgüt, Balkan Antantı ile Küçük İtilaf, Marsilya Suikastı'nın önünde aynı kararlılıkla durmuşlar, böylece "kocaman itilâf'ı kurmuşlardır. Bu kocaman itilafın anlamı, en az kendisi kadar büyüktür. Artık Avrupa hiçbir sindirme politikasının, hiçbir siyasi entrikanın, hiçbir gizli faaliyetin esiri olmaksızın barış yolunda doğru, dürüst ve emin adımlarla yürümeye kararlı olduğunu göstermiştir (Ercüment Ekrem, 22 Teşrinievvel 1934, 3). Bu yüzden gösterilen tavır, barışın acizlik ve zayıflık ile değil, sadece kuvvetin verdiği soğukkanlı emniyetle korunabileceğinin yeni ve parlak bir kanıtı sayılmıştır (Yunus Nadi, 25 Teşrinievvel 1934, 1).

Gerçekleştiği günden bu yana sürekli Marsilya Suikastı'nın Avrupa ile Balkanlardaki barış ve huzura olumsuz etki edebileceğini dile getiren Ebüzziya Zade ise, yayımlanan tebliğin şu ana kadar savunduğu görüşleri haklı çıkardığını ileri sürmektedir. Özellikle tebliğdeki, "gerekli tedbirlerin alınmaması halinde daha vahim sonuçların çıkabileceği” yönündeki kısımlara dikkat çeken Ebüzziya Zade, bu tarz toplantılardan sonra yayımlanan tebliğlerin genellikle net ve sert ifadeler içermeyen, muğlak cümlelerden oluşan bildiriler olduğunu, ancak Belgrat Tebliği'nin bu derece açık hükümler ile dünyayı tedirgin edecek şekilde tehditkâr ifadeler içermesinin önemsenmesi gerektiğini belirtmektedir. Siyasi erkân dahi bu tarz ifadelerle kamuoyuna açıklama yapma gereği duyuyorsa kesinlikle durum sanıldığından daha ciddi idi (Ebüzziya Zade, 21 Teşrinievvel 1934, 1).

Tevfik Rüştü Aras, Belgrat'tan Ankara'ya döndükten hemen sonra edindiği izlenimleri Atatürk'e aktardı. Aldığı bilgiler üzerine Gazi aynı gün yeni Yugoslav kralı II. Pierre’e bir telgraf gönderdi. "Tahta çıkışlarının daha ilk gününde majestelerine, Türkiye'nin sarsılmaz dostluğu hakkında yeniden kesin güvence veririm.” ve "Aynı barış ve güvenlik ideali etrafinda birleşecek olan Türkiye ile Yugoslavya'nın dostça işbirliğini geliştireceklerine dair kesin kanaatim vardır" (Şimşir 1996, 281) diyerek, Türkiye'nin I. Aleksander zamanında kazanılan dostluğunun kendileri zamanında da devam edeceğine dair güvence vermiştir.

Yugoslavya kralı I. Aleksander'ın Marsilya'daki suikastta hayatını kaybetmesi hadisesi, TBMM'nin 24 Ekim 1934 tarihli oturumunda gündeme gelmiştir. Oturumda söz alan Dışişleri Bakanı Tevfik Rüştü Bey; müttefikimiz Yugoslavya'nın büyük kralı I. Aleksander ile Fransa Dışişleri Bakanı Barthou'nun öldürülmeleri üzerine hükümetin derhal üzerine düşeni yaparak, 
askeri ve sivil bir heyeti Belgrat'a gönderdiğini, orada diğer Balkan müttefikleriyle birleşip durumu değerlendirdiklerini ve tam bir mutabakat içerisinde düşüncelerini ifade ettiklerini bildirmiştir. Dost memleketlerin üzüntülerini paylaştıklarını böylelikle ortaya koyarken aynı zamanda Balkan Antantı'nın gittikçe artan bir güçle nasıl sarsılmaz bir kuvvet olduğunu tüm dünyaya göstermişlerdir. Ayrıca verilen tüm taahhütlere Türkiye'nin bağlılığını sürdürdüğünü bir kez daha dile getirme firsatı bulduğunu belirten Aras, suçluların bir an önce bulunması ve benzeri girişimlerin tekrarlanmaması için tüm medeni milletlerin ortak hareket etmesi gerektiğini bildirdiklerini arz etmiştir. Dışişleri Bakanı Aras'ın TBMM'yi bu şekilde bilgilendirmesinin ardından Meclis Başkanı Kazım (Özalp) Paşa, TBMM'deki milletvekillerini vefat edenlere hürmeten bir dakikalık saygı duruşuna davet etmiştir. Tekirdağ Milletvekili Cemil Bey ile beş arkadaşı ise, "Yugoslavya Kıralı birinci Aleksandr Hazretleri ile Fransa Hariciye Nazırı M. Bartu'nun ölümlerinden dolay Meclisin taziyetlerinin yukarıda adı geçen iki millete bildirilmesine dair takriri" Meclis Başkanlığı'na vermiş ve oy birliği takrir kabul edilmiş (TBMM Zabıt Ceridesi, 1934, 3-4), TBMM adına Başkan Kazım (Özalp) Paşa da Yugoslavya ve Fransa meclis başkanlarına ayrı ayrı taziye telgrafları çekmiştir (Akşam 25 Teşrinievvel 1934, 4; Hâkimiyeti Milliye 25 Birinci teşrin 1934, 3).

\section{Suikastın Türk Basını ile Kamuoyuna Yansımaları}

Basında çıkan haberlerde öncelikle kralın hayatı, şahsiyeti ve ülkesi için yaptığı çalışmalar hakkında bilgi verilmiş, ölümünün ise Türkiye'de çok büyük bir üzüntüye sebep olduğu vurgulanmıştır. Kralın Zagrebli Petrus Kalemen isminde 1899 doğumlu bir Hırvat tarafından öldürüldügü gibi suikastın nasıl planlanıp gerçekleştirildiği yönündeki haberler gün gün aktarılmış, edinilen her türlü bilgi kamuoyu ile paylaşılmıştır. Olayın sebepleri hakkında yapılan çeşitli siyasi-diplomatik açıklamalar da yine basında geniş yer bulmuştur.

Falih Rıfkı Bey’e göre kral; I. Dünya Savaşı'nda vatan toprağını sonuna kadar savunan kahraman bir asker, savaştan sonra ise ülkesini gelişmiş devletler seviyesine çıkarmak için yılmadan çalışan bir devlet başkanı idi. Ülkesinin birliği ve selameti için çalışırken vazife başında hayatına kastedilmişti (Falih Rıfk1, 11 Birinci teşrin 1934, 1). Cumhuriyet gazetesinden Yunus Nadi ise, Yugoslavya'nın her tarafında sevilmiş, muhterem, itibarlı, sözü ve özü doğru mert bir hükümdar olan kral Aleksander'ın (Yunus Nadi, 10 Teşrinievvel 1934, 1), aynı zamanda barışı sürdürmenin önemini en üst düzeyde kavramış yüksek karakterli ve bilhassa sözüne güvenilir bir lider olduğunu vurgulamıştır. Zaten "Yugoslavya'yı muhafaza ediniz" şeklindeki son sözlerinin de bu kanaati doğruladığını ve vatanperver kralın yüksek karakterine çok yakıştığını belirtmiştir (Yunus Nadi, 11 Teşrinievvel 1934, 1, 3). Avrupa hükümdarları arasında ahlaken en yükseklerinden biri olup memleketini çok seven, vatanı için birçok fedakârlığa katlanan, gören herkese kendini sevdiren ve mutlu bir aile reisi olan kral I. Aleksander (Ebüzziya Zade, 11 Teşrinievvel 1934, 1) bu niteliklerinin yanında; "memleketinin saadeti için senelerden beri durmadan çalışmış çok kıymetli ve fedakâr bir şahsiyetti. Muharebe senelerinde Sirp ordusu ile beraber harbin bütün sıkıntılarını çeken, harpten sonra da yorulmadan mütemadiyen çalışan genç kral inceliği, zekâsı ve doğru görüşü ile tanınmıştı". Kralın Türkiye'de bu derece sevilip iltifat görmesinin sebebi, eşiyle birlikte 1933 yılında İstanbul'a yaptıkları ziyaret sırasında halk ile iç içe olup kaynaşmasına dayanıyordu. Türk halkının kendisini yakından tanıyıp nezaketi ile inceliğine şahit olması, yukarıdaki kanaati samimi bir şekilde kendiliğinden zuhur ettirmişti. Böylesi feci bir akıbete uğraması bu yüzden tüm Türkiye'yi yasa boğmuştu. Ayrıca şahsi anlamda kralı kaybetmenin üzüntüsüne dünya barışı için çalışan barış yanlısı bir liderin kaybı düşüncesi de eklendiğinden Türkiye'deki yankılar doruk noktasına ulaşmıştır (Akşam, 10 Teşrinievvel 1934, 1). 
Necmeddin Sadık bu durumu Akşam gazetesindeki başyazısında;

"Türkler, geçen sene İstanbul'da Gazimizi ziyaret eden kral Aleksander'ı cidden sevmişlerdir. Onun genç ve sevimli yüzünde, doğru bakışlı gözlerinde Türklüğ̈̈n her devirde hayran olduğu mertlik ve dürüstlük vasıflarını görmüştü. Türkiye ile Yugoslavya, kâğıt üzerine yazılı en kuvvetli muahedelerin mana ve şümulünü geçen, âdeta kendiliğinden doğmuş, sarsılmaz bir dostlukla -kısa zamanda- birbirine bă̆lanmıs iki millettir. Bu dostluğun kuvvetinde, verilmiş söze sadakat şiarının büyük dahli oldu. Kral Aleksander, Yugoslav milletinin timsali olarak, bizim kalbimizde işte, bunun için büyük yer tutmuştu" (Necmeddin Sadık, 11 Teşrinievvel 1934, 1).

sözleriyle açıklamıştır.

Falih Rıfkı ise, kral Aleksander'ın, ölümü ile Yugoslav halkını ne kadar büyük bir ıstıraba sürüklediyse dost milletin huzur ve güvenliğini isteyen Türkiye gibi devletleri de o derece derin bir acıya sevk ettiğini bildirmektedir. Zaten Türk milletinin gerçek ve samimi duyguları, kral Aleksander'1 şahsen tanıyan, onunla Balkan barışı için sözleşen ve bu uğurda birlikte çalışan Gazi hazretlerinin telgrafında en güzel şekliyle özetlenmişti. Türkiye'deki hissiyata böylelikle tercüman olan yazar, devam ederek, suikastçıların bu eylemle elde etmeyi düşündükleri amaçlara kesinlikle ulaşamayacaklarını, Yugoslav halkının krallarının aziz hatırasına bağlılığını sürdürerek eserini bütün tehlikelere karşı koruyacağını, hatta suikastın tüm anlaşmazlıkları ortadan kaldırarak Yugoslav milletlerini birbirlerine, Yugoslavya'yı da dostlarına daha çok yaklaştıracağını bildirmiştir (Falih Rıfkı 11 Birinci Teşrin 1934, 1). Gerçekten de Yugoslavya'nın korunmasına ilişkin sarf edilen son vasiyete Yugoslav halkın dikkatle bağlı kalacağına dair inanç, Türk basının diğer kalemleri tarafindan da altı çizilen bir husus olmuştur (Yunus Nadi, 11 Teşrinievvel 1934, 3).

Hemen hemen Falih Rifkı ile aynı noktalara temas eden Yunus Nadi; Yugoslav milletine duyulan dostluğa eskisinden daha kuvvetli bağlı kalınıp, bu elemli olaydan memnun olanların besledikleri ümitlerin boşa çıkacağını, Türkiye'nin Yugoslavya'ya vermiş olduğu Balkan taahhüdüne dün olduğu gibi bugün ve yarın da tüm kuvvetiyle bağlı kalacağını ifade etmektedir. Ayrıca Yunus Nadi, kral Aleksander'ın şahsında şefini ve insani olarak da kuvvetli bir barış hizmetkârını kaybeden Yugoslavya'nın matemine Türkiye'nin bütün milletçe ortak olduğunu bildirmiştir. I. Dünya Savaşı'nın yok edici etki ve sonuçları karşısında hayatta kalmayı başarıp üstelik muzaffer olarak ülkesini her türlü iç ve dış tehditlere karşı bir bütün halinde tutmayı başaran kralın, tüm felaketleri atlatıp dost bir devlete yaptığı ziyaret esnasında öldürülmesini ise talihin garip bir oyunu olarak yorumlamıştır (Yunus Nadi, 10 Teşrinievvel 1934, 1).

Öte yandan İstanbul'da yaşayan Yugoslav halk, Yugoslav kulübünde bir toplantı düzenleyerek Belgrat'ta oluşturulan Niyabet Meclisi'ne bir taziye telgrafı göndermiştir. Aynı toplantıda Kulüp Reisi M. Tomiç, kral I. Aleksander hakkında bilgi verdikten sonra Türk milletinin ve gazetelerinin acılarına iştirak etmesine teşekkür etmiştir (Akşam 13 Teşrinievvel 1934, 2). Bu teşekkür aslında kralın ölümünün Türkiye'de nasıl yankılandığını, tüm ülkede duyulan üzüntünün Yugoslavların dikkatinden kaçmayacak derecede bariz olduğunu göstermektedir.

Suikastın yaşandığı günlerde Türkiye'de Belediye seçimleri yapıldığı için şehirler baştanbaşa süslenmiş, bayraklarla donatılmıştı. Lakin suikast haberi duyulunca, tüm yurtta şenlikler durdurulmuş, müzik susturulmuş, resmi dairelerle elçiliklerde bayraklar yarıya indirilmiştir (Akşam 10 Teşrinievvel 1934, 4; Hâkimiyeti Milliye 11 Birinci teşrin 1934, 5).

Kralın defnedileceği 18 Ekim Perşembe günü ise milli yas ilan edildiğinden Dâhiliye Ne- 
zareti'nin emriyle tüm ülkedeki tiyatro ve sinemaların kapalı tutulmasına, gazino, kahve gibi yerlerde müzik çalınmamasına, radyoda da kralın şahsi niteliklerinden bahseden konferanslar verilmesine, ayrıca bayrakların yarıya indirilmesine karar verilmiştir (Hâkimiyeti Milliye, 17 Birinci Teşrin 1934, 3; Akşam, 17 Teşrinievvel 1934, 1). Söz konusu kararlar 18 Ekim günü aynen uygulanırken, yine o gün akşam saat 20.30 'da Ankara ve İstanbul radyolarında kral Aleksander'ın ölümünün ülkede uyandırdığı derin üzüntü ile tutulan yasa dair Türkçe, Sırpça ve Fransızca nutuk verilmiştir. Programa Marş Fünebr ile başlayan radyo, kralın hayatı hakkında bilgi verdikten sonra ölümünden Türk milletinin duyduğu acıyı içtenlikle dinleyicilere aktarmış, suikast ile ilgili ajans haberlerinin ardından ise üç dilde yapılan beyanata geçilmiştir. Nutukta; yayının yapıldığı saatlerde Gazi'nin dostu olan kral hazretlerinin toprağa verildiği belirtilerek, katilin tek bir kurşunla kral Aleksander'ın yalnızca bedeni varlığına zarar verdiği, oysa onun temsil ettiği manevi varlığa hiçbir etki yapamadığı vurgulanmıştır. Sadece Yugoslav halkının sergilediği birlik ve soğukkanlılık değil hemen hemen tüm Avrupa'nın Yugoslavya'ya gösterdikleri destek ve dostluk bunu açıkça kanıtlamıştı. Dahası, 1914'te atılan kurşun insanları birbirine düşürerek bir dünya savaşının çıkmasına sebep olurken tam yirmi yıl sonra bir başka kurşun onun aksine barış ülküsüyle herkesi kral Aleksander'ın hatırası ve eseri etrafinda toplamıştır. Radyo'daki nutuk tüm Türkiye'nin halet-i ruhiyesini yansıtır biçimde; "Onun toprăga gömüldügü gün, Türkiye hakikî acı duymuş bir ailenin iztirabını daha şiddetle hissetti. Bu matemin filî tezahürlerini derhal görebilirsiniz. İklimden iklime uzıyan geniş Türkiye topraklarında bu akşam gülen, eğlenen, hattâ şarkı söyliyen bir adam bulamazsınız. Bizim de iztirabımız büyük. Onun için dost Belgrat'a teselli verecek halde değiliz. Biz de teselliye muhtacız." sözleriyle sona ermiştir (Hâkimiyeti Milliye, 19 Birinci teşrin 1934, 2; Cumhuriyet, 19 Teşrinievvel 1934, 6).

Taksim'deki Ayatiryada Kilisesi'nde ise yoğun katılımlı bir ayin düzenlenmiş, İstanbul Valisi Muhiddin Bey ile İstanbul Kumandanı Ali Rıza Bey gibi şehrin önde gelen isimleriyle Mısır ve Danimarka elçileri ve konsolosları da ayinde hazır bulunmuşlardır (Akşam, 18 Teşrinievvel 1934, 2; Akşam 19 Teşrinievvel 1934, 4; Zaman, 19 Teşrinievvel 1934, 7).

Kral I. Aleksander için tutulan yas ve ilk kez bir cenaze merasimi için Türk askeri bölügünün yurt dışına gönderilmesi kararları, Türk kamuoyunun durumu daha net anlayabilmesi için basın erbapları tarafından en güzel şekliyle açıklanmıştır. Öncelikle matem kararının özel bir anlamı olduğu unutulmamalıdır. Zira kral Aleksander, milletinin birlik ve bağımsızlığı için mücadele etmiş bir kahraman olduğu gibi Orta Avrupa ve Balkanlarda da barış ve güvenliğin sağlanmasına gayret eden bir liderdi. Kralın bu birlik, bağımsızlık, barış ve güvenlik düsturları, Türkiye Cumhuriyeti'nin de dayandığı dört temel ilke olduğundan, yas kararı sadece dost bir devletin hayatını kaybetmiş dost lideri için değil, uğruna hayatını ortaya koyduğu bu ilkelere ve aynı temellere dayanan iki devletin birbirine olan sevgi ve saygısına hürmeten alınmış bir karardır. Benzer şekilde Türk birliğinin Belgrat'a gönderilmesi kararı da aynı saygı ve hürmetin özel bir ifadesidir. Ayrıca tüm bu hassasiyetler ile gösterilen ihtimamlar, kralın açmış olduğu barış ve emniyet yolundan sapılmadan ilerleneceğinin, ona bağlı kalınacağının bir delili olarak Türk halkına anlatılmıştır (Falih Rıfkı, 18 Birinci teşrin 1934, 1).

Türk basını, suikastın kim veya kimler tarafindan, neden ve nasıl gerçekleştirildiğine dair elde ettiği bilgileri de günü gününe Türk kamuoyu ile paylaşmış, çeşitli yorumlarda bulunmuştur. İstanbul'daki Yugoslavya Konsolosluğu'ndan alınan yarı resmi nitelikteki bilgilere göre; Petrus Kelemen ismindeki katil sabıkalı bir Hırvat idi. Daha önce Radiç Fırkası'na mensup nazırlardan birini öldürmüş ve Macaristan'a kaçmıştı. Suikastın ise Yugoslavya'da mevcut rejimden memnun olmayan ve Yugoslavya dışına kaçan bazı kimselerin emriyle gerçek- 
leştirildiği tahmin ediliyordu (Cumhuriyet, 11 Teşrinievvel 1934, 7; Hâkimiyeti Milliye, 11 Birinci teşrin 1934, 5; Zaman, 11 Teşrinievvel 1934, 6).

Doğrudan suikast ile ilgili yapılan bir değerlendirmede, Marsilya Suikastı'nın tarihin kaydettiği en büyük siyasi cinayet olduğu tespiti yapılmaktadır. Yalnız Yugoslavya hükümdarı öldürülmekle kalmamış, Fransa'nın mühim bir siyaset ve devlet adamı da onun yanında can vermiştir. İki devletin iki önemli isminin aynı suikastta hayatını kaybetmesi, şimdiye kadar gerçekleştirilen suikastlardan Marsilya Suikastı'nı ayırmaktadır (Muharrem Feyzi, 11 Teşrinievvel 1934, 2).

Sebeplere ilişkin yapılan yorumlara göre ise, her ne kadar suikastta İtalya veya Makedonyalıların parmağı olduğu ileri sürülse de şimdilik bu tür yargılardan kaçınılmalıydı. Bilakis fail bir Hırvat olduğu için doğrudan Yugoslavya'daki iç siyasi çekişmelerin bir sonucu olarak kral Aleksander öldürülmüştü. Ülke içerisindeki Hırvatlar, aslında kendileri de Slav ırkına dayanmasına karşın özellikle uzun bir süre Avusturya-Macaristan İmparatorluğu hâkimiyetinde yaşayıp bu devletin medeniyet ve kültürünü özümsedikleri için Sırp egemenliği altında yaşamak istemiyorlardı. Bu yüzden 1918'den beri Hırvatlarla Sırplar sürekli ihtilaf halinde idi. Hatta 1928 yılında Skupştina Meclisi'nde Hırvat lider Radiç'in öldürülmesi bu husumeti kanlı bir boyuta taşımıştı. Yaşanan tüm bu gelişmeler hem ülke bütünlügünü korumaya çalışan kral Aleksander'1 diktatörlük ilan etmeye zorlamış, hem de 1931'de yeni bir anayasanın hazırlanmasına yol açmıştır. Ancak Hırvatların talepleri yine karşılamadığından aradaki husumet giderek artmış, artık bunun sorumlusu olarak kral Aleksander görülmeye başlandığı için Marsilya Suikastı gerçekleştirilmiştir. Sonuçta, Yugoslavya'nın kendi iç meseleleri bu suikastın temel sebebidir (Ebüzziya Zade, 11 Teşrinievvel 1934, 1-2). Zamanla derinleşen bu hizipleşme suikastın temel nedeni olarak vurgulanırken, Sırp-Hırvat çekişmesinde Hırvatların lehine ülke dışında faaliyet gösterenlerin gerginliği artırmak adına yaptıkları çalışmalar da unutulmamalıdır. Yer yer Fransız ve İngiliz basınında Hırvatların şikâyetlerinin dile getirilmesi, bazı Avrupa siyasilerinin Hırvatların durumunu çeşitli platformlarda acı acı tasvir etmesi gibi durumlar sebep olarak kabul edilemese de suikastı planlayanlara cesaret verici etkenler olarak değerlendirilmiştir (Ö.R., 13 Teşrinievvel 1934, 2).

Suikastın iç karışıklıklardan değil tamamen dış politikada izlenen yanlış siyasetten kaynaklandığını öne süren yorumlar da bulunmaktadır. Nitekim Yugoslavya ile İtalya arasındaki gerginlik, Sırplar ile İtalyanlar arasındaki uzlaşmazlıktan ziyade Hırvatlar ile İtalya arasında gayet eskiye dayanan tarihi husumete dayanıyordu. İki taraf arasındaki düşmanlık, Hırvatistan sahillerine yerleşmek amacıyla saldırılar düzenleyen Venedik Cumhuriyeti dönemine kadar geriye götürülebilirdi. Ancak özellikle I. Dünya Savaşı ile Fiome Meselesi'nde olduğu gibi İtalya'nın izlediği saldırgan politikalar Hırvatlarla İtalyanlar arasındaki eski düşmanlığı artırarak bugüne kadar getirmiştir. Dahası, Hırvat ve Slovenlerin yerleşik olduğu Istra'nın İtalya idaresine bırakılması, Hırvatistan sahillerine hâkim Trieste ile Fiome'nin ve Dalmaçya sahillerindeki stratejik adaların İtalyanların eline geçerek Adriyatik Denizi'nin yukarı kısmına hâkim olmaları Hırvat politikacıları büsbütün kızdırmıştı. Tüm bunları göremeyen Fransa'nın Yugoslavya'yı İtalya ile uzlaştırmaya çalı̧̧ması ise artık son nokta olup Hırvat ihtilal komitelerini harekete geçirdiğinden böylesi bir suikast gerçekleşmişti. Bu yüzden Fransa'nın izlediği yanlış politika suikastın en önemli sebebi idi (Akşam 14 Teşrinievvel 1934, 5).

Suikastta Fransız polisinin ihmali olduğu düşüncesi de yer yer Türk basınında ele alınan bir konu olmuştur. Yeterli tedbirin alınmadığı görüşü sıklıkla dile getirilirken özellikle bu tedbirsizliğin suikastın aydınlatılmasında birinci derecede önem taşıyan katilin öldürülmesi durumu da eklenmiştir. Eğer ki polis gerekli önlemleri aldığı halde yine de suikast gerçekleştirilse ancak 
katilin öldürülmesi engellenirse o takdirde derhal katil sorguya çekilerek gizli kalan noktalar açığa kavuşturulabilirdi. Keza bir katilin olduğu yerde öldürülmesi değil, öldürülmesinin engellenmesi mühim bir polis vazifesidir. Fransız polisinin güvenlik tedbirlerindeki eksiklikleri kral ile Fransız Dışişleri Bakanı'nın hayatına mal olduğu gibi katilin de ölümüne sebep olduğundan suikastın ayrıntıları ortaya çıkarılamamıştır (Yunus Nadi, 12 Teşrinievvel 1934, 1).

Yeterli tedbirlerin alınıp alınmadığının Fransız Elçisi Mösyö De Kamerer'e sorulması üzerine; "suikastı gerçekleştirmeye kendi canını dahi ortaya koyacak şekilde karar vermiş bir kişiyi engellemenin mümkün olmadiğı" cevabı alınmıştır. Elçi, kendi tarihlerinden de örnek vererek iki yıl önce 6 Mayıs 1932'de, Fransa Cumhurbaşkanı Dumerge'nin yanında polis müdürü olduğu halde suikasta maruz kaldığını, engellenemediğini belirtmiştir. Dolayısıyla kendi devlet adamlarını dahi tüm tedbirlere rağmen koruyamayan Fransız Hükümeti'ni Marsilya Suikastı'ndan sorumlu tutup kabahat bulmanın haksızlık olacağını ifade etmiştir (Zaman 12 Teşrinievvel 1934, 1). Aslında Zaman gazetesi yazarı Ebüzziya Zade de aynı fikirdedir. Ebüzziya, bir buçuk asır boyunca pek çok badire atlatarak hürriyet ve medeniyet yolunda önemli bir aşama kat eden Fransa'nın belli bir olgunluğa ulaştığını, kişisel hak ve özgürlüklere İngiltere'den sonra en fazla önem veren ikinci devlet olduğunu belirtmektedir. Böylesi gelişmiş bir medeniyete sahip Fransızların asla böyle bir suikastta dâhillerinin bulunmayacağını, hatta Fransızların gerek kendilerine gerekse ülkelerini ziyaret eden yabancı devlet adamlarına karşı yapılan bütün bu suikastlara hürriyetperverliklerinden, kanunlara uyma arzularından ve medeni gelişimlerinden ötürü maruz kaldıklarını ifade ederek suikasta ilişkin Fransa'ya bir kabahat bulmanın doğru olmayacağını savunmuştur (Ebüzziya Zade, 15 Teşrinievvel 1934, 1-2). Eğer ki suikastın sebebi bağlamında- bir sorumlu aranıyorsa, en genel haliyle ortada tek bir gerçek mesul vardır, o da I. Dünya Savaşı sonunda yapılan "barış antlaşmaları"dır. Gerçekten de sadece Marsilya Suikastı'nın değil, Avrupa ve Balkanlardaki tüm karmaşıklığı doğuran, besleyen ve büyüten en önemli neden I. Dünya Savaşı'nda kazanan devletlerin adaletten ayrılarak hazırladıkları haksız "barış antlaşmaları"dır. Galip devletlerin akıl ve mantıktan yoksun, feci surette hazırladıkları bu barış antlaşmaları nedeniyle savaşın bittiği 1918 yılından bu yana Avrupa'da kanlı vakalar, ihtilaller, bu tarz suikastlar bitmek bilmemekteydi (Ebüzziya Zade, 19 Teşrinievvel 1934, 1-2; 25 Teşrinievvel 1934, 1).

Sebeplerin dışında cinayetin sonuçlarının ne olacağı konusunda üretilen fikirler, daha çok 1914 Saraybosna cinayeti ile yapılan karşılaştırmalar nedeniyle bilhassa uluslararası basında yeni bir dünya savaşının çıkabileceği noktasında toplanmaktaydı. Ancak Türkiye'de böylesi yorumlarda bulunanlar devrin şartlarını tam olarak idrak edemeyenler olarak değerlendirilmiş ve bu tür fikirleri ciddiye almanın zayıflık olacağı vurgulanmıştır. Çünkü suikastçıların, gayri meşru bir komitenin mensubu olup meşru hiçbir iktidarla herhangi bir irtibatlarının olmadığına inanılmaktadır. Kendiliğinden doğabilecek bir kargaşadan istifade edilmesine ise Yugoslav halkının daha ilk dakikadan itibaren sergilemiş olduğu ağırbaşlılık ve metanet engel olacaktır. Ayrıca şimdiki durum, Avrupa'da bir savaşın gerek milli gerekse uluslararası mesuliyetlerini üstelenecek herhangi bir devletin bulunmamasından ötürü oldukça farklıdır. O günkü Avrupalı devletlerin savaşmak için firsat kolladıkları dönem, bugün için geçerli olmadığından herhangi bir savaş çıkma ihtimali bulunmamaktadır (Falih Rıfkı, 15 Birinci Teşrin 1934, 1).

Öte yandan, doğrudan bir savaşa yol açmamakla birlikte vahim sonuçlar doğurabilme ihtimalinin olduğu göz ardı edilmemelidir. Şöyle ki, katil her ne maksatla bu eylemi gerçekleştirirse gerçekleştirsin her şeyden önce ülkesine ve milletine ihanet etmiştir. Çünkü siyasi cinayetler, mutlaka hedefledikleri amacın tersine ve zararlı sonuçlar doğurur, arkasından da bir karışıklığı, ihtilali, hatta bir çöküşü sürükleyip getirir. Hele ki öldürülen kral I. Aleksander gibi ülkesini 
birlik ve beraberlik içinde tutmayı başarmış bir liderse böylesi ihtimallerin gerçekleşme olasılığ daha yüksektir. Şimdi Hırvatlar istedikleri muhtariyete kavuşsalar bile ülkeyi tek çatı altında tutacak bir başka Aleksander olmadığından ve kralın ölümünden istifade etmeye çalışacak olanlar en başta iç kargaşayı arttıracaklarından Yugoslavya'nın dış politikadaki gücü zaafa uğrayacaktır. Bu ise Küçük İtilaf'ı zayıf düşürebileceği gibi İtalya'nın da bundan yararlanmasına sebep olabilir. Aynı şekilde Bulgaristan'daki kabinenin durumunu da güçleştirebileceğinden buradaki Makedon İhtilal Komitesi'nin yeniden faaliyete geçmesine yol açabilir. Fransa'nın eskisi kadar Küçük İtilaf'a güvenememesi de eklenirse o zaman bütün bu kargaşadan Almanya, Avusturya ve Macaristan istifade etmeye kalkışabilir. Neticede suikastın sonuçları sadece Yugoslavya ile sinırlı kalmayıp bütün Avrupa siyasetini etkileyebilecek bir mahiyet arz edebilirdi (Ebüzziya Zade, 11 Teşrinievvel 1934, 1-2; 13 Teşrinievvel 1934, 1).

Suikastın muhakkak olumsuz yönde siyasi sonuçlar doğuracağı iddiasına bir başka gerekçe, Avrupa'da uyum ve barışın egemen olması için çalışan üç büyük isimden, yani Kral Aleksander, L. Barthou ve Mussolini'den ikisinin, Aleksander ve Barthou'nun öldürülmüş olmasıydı. Bunlardan en etkini Barthou olup eski ittifakları güçlendirmek için Varşova, Prag, Bükreş ve Belgrat seyahatlerini gerçekleştirmiş, yeni ittifaklar kurmak için de Sovyet Rusya ile anlaşmış bir kişi idi. Son dönemde ise Fransa ile İtalya'yı uzlaştırmaya çalışıyordu. Fakat bunun için önce İtalya ile Yugoslavya'yı kaynaştırması gerekmekteydi. Bu uğurda çalışılırken hatta tam da İtalya-Yugoslavya anlaşmazlıklarının görüşülmesi için Marsilya'ya gidildiği sırada suikast gerçekleştirildi. Artık ne uzlaştırıcı roldeki Barthou ne de Avrupa ve barışı için çalışan Aleksander vardı. Sonuçta Yugoslavya ile İtalya'nın anlaşma ihtimali şu an için ortadan kalktığına göre olumlu seyreden diplomatik ilişkiler tekrar kopma noktasında ilk olumsuz sonucunu doğurmuştu. Diğer yandan Fransa'nın Almanya'yı kuşatmak amacıyla oluşturmaya çalıştığ dostluk ve ittifaklar çemberi de yine şimdilik tamamlanmadığından bu da yine siyasi bir sonuç olarak değerlendirilirdi (Muharrem Feyzi, 15 Teşrinievvel 1934, 2).

Yukarıdaki görüşlerin pek de haksız olmadığını gösteren ilk emareler ise 11-12 Ekim'de görülmeye başlanmıştır. Söz konusu tarihlerde yayımlanan bir habere göre; Amerika'daki Hırvat Milli Komitesi temsilcisi, kral Aleksander'ın ölümünün bir cinayet değil, Hırvatların Aleksander hakkında daha önce verdikleri idam hükmünün infazı olduğunu beyan etmiştir (Akşam, 11 Teşrinievvel 1934, 2; Cumhuriyet, 12 Teşrinievvel 1934, 5). 17 Ekim'de Bulgaristan'dan gelen Makedonya Komitesi'ne ilişkin bir başka haber tedirginliği büsbütün artırır mahiyette idi. "Makedonya Hayırperver Kardeşlik Cemiyetleri Birliği" adına yayımlanan beyannamede cemiyetin amaçları; Makedonların "Makedonya hakkındaki emel ve gayeye aşkla bağlanmalarını ve vatana olduğu gibi milli maksada hizmet edici olmalarını", "esir ve mahkûm kardeşlerinin vaziyetleri ile alâkadar olmalarını" temin etmek şeklinde bildirilmiştir. Açıklamanın sonunda ise; "Ana vatanlarından kovulan Makedonyalılar vatanlarını ve ocaklarını hiçbir zaman unutmayacaklardır. Vatanların sevmekten ve düşünmekten onları menedecek hiçbir kuvvet yoktur. Bunun için millî Komite mahkûm yaşayan millettaşlarının vaziyetlerinin ıslahını bütün Bulgar milletinin menfaati bilerek faaliyette bulunacaktır." (Zaman, 17 Teşrinievvel 1934, 2; Cumhuriyet, 17 Teşrinievvel 1934, 1, 5) denilmekteydi. Anlaşılacağı üzere beyanname, Makedon İhtilal Komitesi'nin isim değiştirerek tekrar faaliyete geçtiğini, Bulgar Hükümeti'nin de bu komite ile başa çıkamayıp varlığını kabul etmek zorunda kaldığını gösteriyordu. Dolayısıyla Marsilya Suikastı'ndan sonra her ne kadar Balkanlar ile Avrupa'da barış ve güvenliğin tesis edilmesine ilişkin çeşitli temenniler ileri sürülse de en azından Makedon coğrafyası ile Balkanların genelinde söz konusu komiteden ötürü huzursuzluğun devam etme ihtimali bulunmaktaydı (Ebüzziya Zade, Zaman, 18 Teşrinievvel 1934, 1-2). 
Sebep ve sonuçlar bağlamında öne sürülen bu tür çıkarımlar göstermektedir ki, Marsilya Suikastı'nda, izlenen dâhili ve harici siyasetlerin her ikisinin de etkisi bulunmaktadır. Bu yüzden siyasi tesirlerinin gayet geniş mikyasta olacağı ve uzun süre devam edeceği tahmin edilmektedir. Lakin şu an için kanaat, herhangi bir devletin entrikası, teşvik ve tertibi olmadığı için Avusturya'daki Nazi kıyamı ve Başvekil Dollfuss'ün katli olayı kadar bu suikast Avrupa barışını tehdit etmeyecektir (Muharrem Feyzi, 11 Teşrinievvel 1934, 2).

Son olarak belirtilmelidir ki; gerek Yugoslavya'nın kendi içinde yaşadığı siyasi gelişmeler esnasında gerekse I. Aleksander'ın ölümünden önce ve sonra iktidarı konusunda yapılan değerlendirmelerde krala zaman zaman "diktatör" denildiği görülmüştür. Oysa Türk Hükümeti’nin yayın organı olarak kabul edilebilecek olan Hâkimiyet-i Milliye gazetesi başyazarı Falih Rıfkı; "Kral Aleksandr bir diktatör değil, Yugoslavya'nın hayat ve istiklâl meselesi olan millî vahdet etrafindaki büyük ve bükülmez azmin bir ifadesi, bir timsali idi." (Falih Rıfk1, 25 Birinci teşrin 1934, 1) ifadelerini kullanarak, Türkiye'nin kral I. Aleksander'a bakışını net bir şekilde ortaya koymuştur. Ebüzziya Zade de, kral Aleksander için, ülkesindeki iç çekişmelerden dolayı birlik ve beraberliğin korunması adına "diktatörlük ilân etmeğe mecbur oldu" (Ebüzziya Zade, 11 Teşrinievvel 1934, 1) demektedir. Neticede Türk tarafına göre, kral I. Aleksander bir diktatör değil ülkesinin birlik ve bütünlügü için çalışmış, tehlike anında ülkesinin selameti için kendi isteği ile değil mevcut şartların zorlamasıyla bazı yetkileri elinde toplamak zorunda kalmış ve tüm bunların bedelini hayatı ile ödemiş bir liderdir.

\section{Sonuç}

Yugoslavya kralı I. Aleksander'ın, kendi ülke tarihinin yanı sıra Balkan ve Türk tarihi açısından da önemli bir isim olduğu rahatlıkla söylenebilir. Nitekim Balkan Savaşlarında önce Osmanlı Devleti ile sonra Bulgaristan ile savaşan önemli bir komutan olarak ismini duyurmaya başlamıştır. I. Dünya Savaşı'nın patlak verdiği tarihlerde ülke fiilen onun kontrolünde idi. Savaş sırasında ise Osmanlı Devleti'nin karşısında yer alan ülkesi için aktif roller üstlenmişti. Buna karşın savaşın hemen ardından Anadolu'ya asker çıkarmaları isteğinde bulunan İngilizleri geri çevirmeyi bilmiştir. Sırp Krallı̆̆ı'nı, önce 1918'de Sırp-Hırvat-Sloven Krallığı'na, ardından 1929'da Yugoslavya Krallığı'na dönüştürerek, sınırları içerisindeki tüm halkları kaynaştırmaya çalışan bir yönetim izlemeye çalışmıştır. Ayrıca Balkanlardaki istikrarının Dünya barışı için şart olduğunu düşünerek Balkan Antantı'nın yapılabilmesi için yoğun bir gayret sarf etmiştir. Söz konusu çabaları esnasında Türkiye'yi ilk ve son defa ziyaret etme firsatı bulmuş ve Gazi Mustafa Kemal Paşa ile "asker arkadaşı" olmak istediğini belirtecek düzeyde yakın dostluk kurmuştur.

İki lider arasındaki dostluk bağlarının bu kadar kuvvetli olmasına her iki liderin ortak bir asker/devlet adamı kimliğine sahip olması büyük katkı sağlamıştır. Hatta asker ve siyasetçi kimliklerinin her iki liderde de ardı sıra hemen hemen aynı dönemlerde etkin olması, sorunların çözümünde birbirlerine paralel bakış açıları sağlamıştır. Bu duruma en iyi Balkan Antantı'nın kuruluş sürecinde karşılaşılan sıkıntıların aşılması örnek gösterilebilir. Sıklıkla ortak noktalarda buluşmaları, söz konusu dostluklarının derinleşmesinde etkili olmuştur. Bu durum aslında devletler ve milletler arası ilişkilerin liderler özelinde nasıl olması gerektiğini de ortaya koymaktadır. Her devletin kendi milli menfaatlerini gözeterek ancak diğerinin aleyhinde olmayacak şekilde karş11klı anlayış üretebilmesinde liderlerin rolünün büyük bir öneme sahip olduğu ortadadır. Gazi ile kralın dostluğu, buna bir emsal oluşturduğu gibi Türk ve Yugoslav halkın yakınlaşmasını da sağlayan bir etken olmuştur.

Kral I. Aleksander, komşu ülkeler nezdinde yaptığı girişimlerle barışı korumayı ve milletini 
bir savaş tehlikesinden uzak tutmayı amaçlamıştı. Bu hedef doğrultusunda birçok devletin (Bulgaristan, Romanya, Yunanistan, Arnavutluk, Fransa) lideriyle temasa geçtiği gibi Mustafa Kemal Paşa ile de görüşerek kalıcı bir dostluk kurmuştur. Bu açıdan, yani özellikle Balkanlarda birlikte hareket ederek güçlü bir pakt oluşturmayı hedeflemeleri bakımından, iki liderin diğerlerinden farklı olarak daha fazla ön plana çıktıkları belirtilmelidir.

Ayrıca suikasttan birkaç ay önce Bulgaristan'dan kaçan IMRO liderlerinden Ivan Michalilof tutuklatılması, Mustafa Kemal Paşa'nın sadece Balkanlar değil tüm dünya için barış istediğini gösteren küçük ama önemli bir örnektir. Bu hareket tarzı ile Gazi, hem Yugoslavya kralı I. Aleksander'a dostluğunu göstermiş, hem de birbirlerinin aleyhine herhangi bir zararlı girişime destek verilmeyeceği şeklindeki Balkan Antantı hükümlerine uygun hareket ederek bölgede barış ve huzurun tesis edilmesi için elinden geleni yapmıştır. Bu durum aynı zamanda hem uluslararası suçluların nerede olursa olsun tutuklanması ve iadesi gerektiğini hem de hukuka uygun her türlü antlaşma hükümlerine uyulmasının barış ve huzurun tesisi için ne kadar elzem olduğunu göstermesi açısından örnek alınması gereken bir davranış şeklidir.

Diğer taraftan I. Aleksander'ın 1929-1934 arası dönemde aldığı kararlar neticesinde diktatörlükle itham edilmesi, zaten elinde olan tüm iktidara hâkim olmaya çalışma düşüncesinden değil ülke içinde ortaya çıkan ayrılıkçı hareketlerin diğer bazı Avrupalı devletler tarafından desteklenerek iyice palazlanması ve bunun yarattığı iç karışıklıkların ülkeyi parçalanmaya götüreceği endişesinden kaynaklanmış olabilir. Bu bağlamda "diktatörlük" iddiasına en önemli gerekçe olarak sunulan ülkenin idari düzeninin değiştirilmesinin, yerel milliyetçilik ile bölücü ayrımcılığın ortadan kaldırılabilmesi için gerçekleştirilmiş olduğu ihtimalini göz ardı etmemek gerekir. Ancak, her ne kadar diktatörlük yönetiminin tam anlamıyla uygulanmaya başladığ 1 iddia edilen 1931 yılından öldürüldüğü 1934 yılına kadarki üç yıllık dönemde düzeni sağlayarak tekrar demokratik düzene geçebilme imkânı olduğu halde bunu "yapmaması" durumu, I. Aleksander'ın gerçekten diktatörlük kurmak istediği ihtimalini de kuvvetlendirmektedir. Lakin bir de bunu "yapamama" durumu vardır. Demokrasiyi tesis edebilmek için önce ülke içindeki istikrarı sağlamak gerektiğinden yola çıkarak bu amaç için çalışırken hayatına kastedilerek bunun engellenmiş olabileceği ihtimali, "diktatör" şeklindeki ithamın haksız olabileceği düşüncesini akla getirmektedir. Devlet içindeki sıkıntıların, özellikle de dış destekli farklı grupların körüklediği kaosun giderilmesi için üç yıl oldukça kısa süre olarak da değerlendirilebilir. Gelecek hakkında çok fazla varsayımlarda bulunulamayacağına göre, bu noktada en azından o dönemin şartlarına göre siyasi bir refleks sonucu I. Aleksander'ın ülkesini Jakobenist bir anlayışla parçalanmadan kurtarmak için böylesi bir hamle yaptığg düşünülebilir. Ancak şurası kesindir ki, o günün Türk devlet erkânı Yugoslavya'da bir diktatörlük rejimi olduğunu kabul etmekle birlikte kral I. Aleksander'ı asla bir diktatör olarak görmemiştir. Mevcut olumsuz şartların zorlaması sonucunda ülkesinin birlik ve beraberliğini korumak amacıyla bunu ilan etmek mecburiyetinde kalmış bir lider olarak değerlendirilmiştir.

Suikasttan önceki bazı siyasi gelişmelerle birlikte düşünüldügünde ise Yugoslavya kralı I. Aleksander'ın varlığı kadar yokluğunun da İtalya'nın genişleme politikalarını zaman zaman geçici olarak değiştirmesine sebep olduğu söylenebilir. Bu noktada kral I. Aleksander'a Aralık 1933 'te düzenlenen ilk suikast girişimi ile 9 Şubat 1934'te Balkan Antantı'nın kuruluşunu ve 9 Ekim 1934 tarihli Marsilya Suikastı'nı birlikte okumak gerekir. Zira İtalya, gözü olduğu Yugoslav topraklarına hâkim olmak amacıyla Yugoslavya'daki ayrılıkçı hareketlere destek verip, onu parçalamak suretiyle hedefine ulaşmaya çalışmıştır. Bu hamleye karşı I. Aleksander, Küçük Antant'ın dışında, kurulmasına gayret ettiği Balkan Antantı ile cevap vermeye çalışmıştır. Özellikle Balkan Antantı'nın kuruluşunda önemli bir mihenk taşı olan Romanya, Bulgaristan, Tür- 
kiye, Yunanistan ve Arnavutluk ziyaretlerinin hemen ardından gerçekleştirilen ilk suikast girişimi bunu göstermektedir. İtalyan planlarının karşısında alternatif savunma paktlarıyla duran I. Aleksander, ortadan kaldırılırsa tekrar aynı yönde politikalara devam edilebilirdi. Ancak bu ilk teşebbüs gerçekleşmediği için İtalya kısa bir süre Balkanlar üzerindeki politikasına ara vermiş gibi görünerek yönünü Afrika'ya çevirip Habeşistan'a (Etiyopya) saldırı hazırlıklarına başlamıştır. Aynı süreçte ise önündeki en önemli engelin ortadan kaldırılması için Ustasha örgütüne son şansını vermiştir. Ne zaman ki Marsilya Suikastı ile kral I. Aleksander'ın hayatına son verilmiş, hemen ardından İtalya tekrar ama bu kez doğrudan Balkanlara yönelmiştir. Nitekim II. Dünya Savaşı başlayınca İtalya Almanya, Macaristan ve Bulgaristan ile birlikte Yugoslavya'yı işgal etmiş, akabinde de Ustasha liderleri Hırvatistan'ın kurulduğunu açıklamışlardır.

1930'lardan itibaren Avrupa'da başka liderlerin de suikastlarla ortadan kaldırıldığı düşünülürse, Marsilya Suikastı'nın kişisel bir husumet neticesinde değil, geniş bir örgütlenme sonucunda gerçekleştirildiği anlaşılır. Aslında geniş bir perspektiften bakıldığında suikastın özellikle Avrupa'daki revizyonist (Almanya, İtalya, Macaristan vb.) devletlerle anti-revizyonist (Fransa, Yugoslavya vb.) devletlerin çatışmasının bir sonucu olduğu görülür. Sadece kişisel anlamdaki failler belirlenirken görünmeyen uluslararası destek ve azmettiriciler bilinen bir sir olarak kalmışlardır.

Balkan Antantı ile Küçük Antant'ın ortak ve birleştirici üyesi olan Yugoslavya, aynı zamanda doğu ile batı arasında uzlaştırıcı, kaynaştırıcı bir köprü vazifesi görmekteydi. Bu yüzden ortak paydaya yapılan saldırının her iki örgütü de derinden etkilediği, her iki örgüte üye devletlerin bulunduğu Balkanlarda da istikrarsızlığa sebep olduğu söylenebilir.

Zira Balkan Antantı, gerçek kişi olarak önemli bir kurucusunu/destekçisini kaybetmiştir. Yerine gelenler Balkan Antantı'nın yaşaması için samimi bir irade ortaya koyamadığından Antant'ın Yugoslavya ayağı işlevsiz kalmaya başlamış, diğer üye devletlerin de fazla gayretli davranmaması üzerine dağılmaya mahkûm olmuştur. Bu ise kral Aleksander ile Mustafa Kemal Paşa'nın öngörülerinin haklı çıktığını göstermektedir. Her iki lider de Balkanlarda birlik sağlandığı takdirde güçlü ve dirayetli olunabileceğini, parçalanmış bir Balkan coğrafyasının diğer devletler tarafindan ele geçirileceğini iddia etmişlerdi ki, II. Dünya Savaşı da bunu göstermiştir. Bu çerçevede suikast, Balkan Antantı'na yani statüko yanlısı politika izleyen devletlere karşı bir saldırı olarak değerlendirilebilir.

Suikast, aynı zamanda Küçük Antant'ın birlik ve bütünlüğünü de olumsuz yönde etkilemiştir. I. Dünya Savaşı'ndan bu yana Almanya'ya karşı temkinli bir siyaset izleyip Avrupa'daki diğer devletlerle ittifaklar yapmak suretiyle gücünü artırma yoluna giden Fransa'nın kendi dışişleri bakanının ölümüne dahi seyirci kalması, Küçük Antant ve dünya devletleri arasında Fransa'nın prestij kaybetmesine sebep olmuştur.

Son olarak, suikastın Türkiye'de duyulduğu sıralarda yerel seçimlerin yapıllyor olmasına, bu nedenle siyasi havanının gergin, yoğun ve heyecan içinde bulunmasına rağmen yine de haberin büyük üzüntüyle karşılandığını belirtmek gerekir. Suikastla ilgili her türlü gelişme Ankara'daki siyasi aktörler başta olmak üzere tüm yurtta dikkatle izlenmiştir. Seçim atmosferinde yaşanan sevinç ve kutlamalar bir anda sona erdirilmiş, Türk halkı ve siyasi liderleri, Yugoslav halkının matemine ortak olarak aynı hüznü yaşamıştır. Hatta Türkiye Cumhuriyeti Devleti, tarihindeki pek çok ilki, sevgili dostu Yugoslavya kralı I. Aleksander için ortaya koymuştur. Türkiye'nin tarihinde ilk defa yabancı bir devlet başkanı için cenaze merasim günü matem ilan edilmiş, tüm yurtta bayraklar yarıya indirilmiş ve cenaze töreni için ilk kez bir askeri bölük yurtdışına gönderilmiştir. Dünya tarihinde ise Marsilya Suikastı kayda alınan ilk suikast olma özelliğini taşımaktadir. 


\section{KAYNAKÇA}

Armaoğlu F. (2015). 20. Yüzyll Siyasî Tarihi 1914-1995. İstanbul 2015.

Armstong H. F. (1935). “After the Assassination of King Alexander”. Foreign Affairs 13/2 (1935) 204-225.

Atatürk’ün Milli Dış Politikası (Milli Mücadele Dönemine Ait 100 Belge) (1919-1923) (1994). Cilt 2. Ankara 1994.

Baerlein H. (1922). The Birth of Yugoslavia. Volume II. London 1922.

Balkanicus (1934). “Alexander I of Yugoslavia: King, Soldier, and Statesman”. World Affairs 97/4 (1934) 219-222.

Banac I. (1997). "Sırbistan'da Milliyetçilik". Yay. Haz. K. Saybaşı1ı \& G. Özcan, Yeni Balkanlar, Eski Sorunlar. İstanbul (1997) 87-116.

Düstur (1955). Tertip 3. Cilt 15. Ankara 1955.

Ebüzziya Zade. (1934, Teşrinievvel 11). “Facia!”. Zaman, p.1.

Ebüzziya Zade. (1934, Teşrinievvel 13). "Ne Olacak?”. Zaman, p.1.

Ebüzziya Zade. (1934, Teşrinievvel 15). "Medenî Tekâmül”. Zaman, p.1-2.

Ebüzziya Zade. (1934, Teşrinievvel 18), "Faaliyete Geçiyorlar mı?”. Zaman, p.1-2.

Ebüzziya Zade. (1934, Teşrinievvel 19). “Kabahat Kimde?”. Zaman, p.1-2.

Ebüzziya Zade. (1934, Teşrinievvel 21). “Haberler Fena!”. Zaman, p.1.

Ebüzziya Zade. (1934, Teşrinievvel 25). “Adaletsizlikle İş Yürümez!”. Zaman, p.1.

Ercüment Ekrem (1934, Teşrinievvel 22). "Kocaman İtilâf”. Cumhuriyet, p.3.

Erden Ö. (2006). Mustafa Kemal Atatürk Döneminde Türkiye'yi Ziyaret Eden Devlet Başkanları. Ankara 2006.

Falih Rıfkı. (1934, Birinci teşrin 11). "Kıral Aleksandr”. Hâkimiyet-i Milliye, p.1.

Falih Rifkı. (1934, Birinci teşrin 15). "Belgrat'ta". Hâkimiyeti Milliye, p.1.

Falih Rıfkı. (1934, Birinci teşrin 18). "Yas Günü”. Hâkimiyeti Milliye, p.1.

Falih Rıfkı. (1934, Birinci teşrin 21). "Belgrat Toplantıları". Hâkimiyeti Milliye, p.1,3.

Falih Rıfkı. (1934, Birinci teşrin 25). "Millet Meclisinde”. Hâkimiyeti Milliye, p.1.

Graham S. (1938). Alexander of Jugoslavia. London 1938.

Gürkan T. (1971). Atatürk'ün Uşăğının Gizli Defteri. İstanbul 1971.

Güveloğlu G. K. (2012). "SHS ve Yugoslavya Krallığı’nın Türkiye ile Diplomatik İlişkileri (19231938)”. Eds. Y. Okay \& T. Babal, Türkiye-Sirbistan Ilişkileri. İstanbul (2012) 143-190.

Güveloğlu G. K. (2015). "Marsilya Suikasti (Yugoslavya Kralı Aleksander'in Öldürülmesi) ve Türkiye'deki Yankıları-9 Ekim 1934”. Tarih Araştırmaları Dergisi (TAD) 34/57 (2015) 249-269.

Karahasan M. K. (1994). "Mustafa Kemal Atatürk'ün Barış Felsefesi Işı̆̆ Altında Türkiye-Yugoslavya Dostluk İlişkileri”. XI. Türk Tarih Kongresi, Kongreye Sunulan Bildiriler (5-9 Eylül 1990). Cilt VI (1994) 2535-2570.

Lord Kinross (2007). Atatürk Bir Milletin Yeniden Doğuşu. Çev. N. Sander. İstanbul 2007.

Morawski K. S. (2016). "The Assassination of King Alexander I of Yugoslavia in the Light of Archival Press Articles”. Studia z Dziejów Rosji i Europy Środkowo-Wschodniej 51/1 (2016) 47-76.

Muharrem Feyzi. (1934, Teşrinievvel 11). "Marsilya Suikasti”. Cumhuriyet, p.2.

Muharrem Feyzi. (1934, Teşrinievvel 15). “Cinayetin Siyasî Tesirleri Ne Olacak?”. Cumhuriyet, p.2.

Necmeddin Sadık. (1934, Teşrinievvel 11). "Prens Piyer Dün Kral İlân Edildi”. Akşam, p.1.

Necmeddin Sadık. (1934, Teşrinievvel 22). "Mühim Bir Tebliğ". Akşam, p.1-2.

Ö. R. (1934, Teşrinievvel 13). "Yugoslavya Kralının Katli”. Zaman, p.2.

Özgiray A. (1999). “Türkiye-Yugoslavya İlişkileri (1920-1938)”. Tarih İncelemeleri Dergisi (TID) XIV (1999) 11-24.

Seton-Watson H. (1946). Eastern Europe Between the Wars 1918-1941. London 1946.

Seton-Watson R. W. (1932). “The Yugoslav Dictatorship”. International Affairs (Royal Institute of Inter- 
national Affairs 1931-1939) 11/1 (January 1932) 22-39.

Seton-Watson R. W. (1935). "King Alexander's Assassination: Its Background and Effects”. International Affairs (Royal Institute od International Affairs 1931-1939) 14/1 (1935) 20-47.

Soyak H. R. (2014). Atatürk'ten Hatıralar. İstanbul 2014.

Soysal İ. (2000). Tarihçeleri ve Açılamaları ile Birlikte Türkiye'nin Siyasal Andlaşmaları. Cilt I (19201945). Ankara 2000.

Sudetic C. (1992). "Historical Setting”. Eds. Glenn \& E. Curtis, Yugoslavia: A Country Study. Washington (1992) 1-57.

Şimşir B. N. (1981). “Atatürk'ün Yabancı Devlet Adamlarıyla Görüşmeleri, Yedi Belge (1930-1937)”. Belleten XLV/I-177 (1981) 157-207.

Şimşir B. N. (1996). Bizim Diplomatlar. Ankara 1996.

Şimşir B. N. (2001). Atatürk ve Yabancı Devlet Başkanları. Cilt IV. Ankara 2001.

TBMM Zabıt Ceridesi (1934). Devre: 4, İçtima: 3, Cilt 24 (24 Ekim 1934). Ankara 1934.

“The New Kingdom of Jugoslavia”. Foreign Affairs 8/2 (1930) 297-300.

Tomasic D. (1940). “Constitutional Changes in Yugoslavia”. Political Science Quarterly 55/4 (1940) 582-593.

Us A. (1936). Yugoslavya'da Seyahat Notları. İstanbul 1936.

Yunus Nadi. (1934, Teşrinievvel 10). “Kral Aleksandr'n Feci Ölümü”. Cumhuriyet, p.1.

Yunus Nadi. (1934, Teşrinievvel 11). "Dost Milletlerin Büyük Matemleri Karşısında". Cumhuriyet, p.1,3.

Yunus Nadi. (1934, Teşrinievvel 12). "Marsilya Faciasından Sonra Beynelmilel Vaziyete Bir Nazar". Cumhuriyet, p.1.

Yunus Nadi. (1934, Teşrinievvel 25). "Küçük ve Balkan İtilâflarının Tesanüt Misali”. Cumhuriyet, p.1.

\section{BCA Kaynakları}

Başbakanlık Cumhuriyet Arşivi (BCA). Fon kodu/Yer No (Tarih), 30.10.0.0 / 250.691.15 (19.10.1929).

BCA. 30.10.0.0 / 250.691.22 (18 Haziran 1930).

BCA. 30.10.0.0 / 251.692.8 (4 Ekim 1931).

BCA. 30.10.0.0 / 246.667.2 (21 May1s 1932).

BCA. 30.10.0.0 / 251.694.6 (28 May1s 1932).

BCA. 030.10.00.00 / 251.695.1 (4 Ocak 1933).

BCA. 30.10.0.0 / 251.695.32 (24 Nisan 1933).

BCA. 30.10.0.0 / 251.696.2 (8 Mayıs 1933).

BCA. 30.10.0.0 / 200.366.22 (4 Ekim 1933).

BCA. 030.10.00.00/251.696.22 (25 Kasim 1933).

BCA. 30.10.0.0 / 252.698.19 (1934).

BCA. 30.10.0.0 / 226.525.20 (Ocak 1934).

BCA. 30.10.0.0 / 242.634.4 (9 Haziran 1934).

BCA. 30.18.1.2 / 48.69.1 (13 Ekim 1934).

BCA. 30.10.0.0 / 252.698.15 (19 Aralık 1934).

BCA. 30.18.1.2 / 51.3.19 (13 Ocak 1935).

BCA. 30.10.0.0 / 221.491.17 (22 Ocak 1935).

BCA. 30.10.0.0 / 253.702.8 (25 Eylül 1936).

\section{Gazeteler}

Akşam (1934, Teşrinievvel 7, 10, 11, 13, 14, 15, 17, 18, 19, 25).

Cumhuriyet (1934, Teşrinievvel 10, 11, 12, 17, 19, 21).

Hâkimiyeti Milliye (1934, Birinci teşrin 10, 11, 13, 16, 17, 19, 21, 25).

Zaman (1934 Teşrinievvel 10, 11, 12, 13, 14, 15, 17, 19). 